\title{
Rock support prediction based on measurement while drilling technology
}

\author{
Jeroen van Eldert ${ }^{1}$ (D) $\cdot$ Johan Funehag $^{1} \cdot$ David Saiang $^{1} \cdot$ Håkan Schunnesson $^{1}$
}

Received: 3 December 2019 / Accepted: 7 August 2020 / Published online: 20 August 2020

(C) The Author(s) 2020

\begin{abstract}
In tunnelling, rock mass support is designed based on the observed rock mass conditions. These conditions are determined by rock mass characterization. Measurement while drilling (MWD), one such characterization method, acquires drill parameter data during drilling. These data can be used to predict rock mass conditions ahead of the face. In this study, grout-hole MWD data are collected at one of the main tunnels in the large infrastructural project Stockholm bypass tunnels. The normalized and filtered MWD data are correlated to the rock mass characteristics using multilinear regression and the Levenberg-Marquardt method. Although a strong numerical correlation cannot be obtained, the results are promising. As a result, a holistic visual approach, which linked the MWD parameters with the rock mass classification and rock support requirements, was developed.
\end{abstract}

Keywords Measurement while drilling $\cdot$ Rock support $\cdot$ Tunnelling $\cdot$ Rock mass characterization

\section{Introduction}

In Scandinavian hard rock tunnelling, the preferred excavation method is conventional drill and blast excavation. This method has the flexibility required to excavate varying tunnel cross-sections under changing rock mass conditions. In general, hard rock tunnel excavations are initiated by pre-grouting to seal the rock mass and prevent water ingress. The excavation activities themselves consist of blast-hole drilling, blasting, mucking and ground support installation. In practice, the rock mass support is based on predefined rock support classes updated by observations during the tunnel excavation. These observations follow standardized rock mass characterization systems, such as Bieniawski's (1973) rock mass rating (RMR), Barton et al.'s (1974) quality system ( $Q$-system) or Hoek and Brown's (1997) geological strength index (GSI). In Swedish practice, the rock mass quality is established during the site investigation. During the excavation, the predicted rock mass quality is verified, and when required, the rock support is altered, according to the

Jeroen van Eldert

jeroen.van.eldert@1tu.se

1 Division of Mining and Geotechnical Engineering, Department of Civil, Environment and Natural Resources Engineering, Luleå University of Technology, Luleå, Sweden observational method (Peck 1969). Geotechnical mapping is usually performed each blast round (2-m to 6-m sections) along the tunnel. In some cases, the determination of rock class is based on the poorest rock conditions in the mapped section, ignoring the better rock mass conditions in the remainder of the blast round. This worst-case approach ensures tunnel safety but results in over-supporting of the tunnel.

The measurement while drilling (MWD) technology documents various drilling parameters (e.g. penetration rate, operational pressures, rotation speed, flushing flow) while drilling. These raw data are then normalized and filtered (Schunnesson 1998; Van Eldert et al. 2020a,b), to remove operator and machine influences, as well as effects from the drilling process, such as drill-hole collaring and rod extensions (Van Eldert et al. 2020b).

The normalized penetration rate and normalized rotation pressure have been identified as able to portray rock mass fracturing to a great extent (Schunnesson 1996; Rødseth 2013; Martinsson and Bengtsson 2010; Ghosh et al. 2017; Van Eldert et al. 2020a). Schunnesson (1996) showed the correlation between the MWD data and the rock quality designation (RQD, Deere 1964) observed at rock masses in Glödberget, Sweden. The hardness index (drillability based on normalized penetration rate) and fracture index (heterogeneity of the rock mass) are based on variations of the normalized penetration rate and rotation pressure. Martinsson and Bengtsson (2010) applied the MWD fracture, hardness and water indices to determine additional grout-hole requirements 
at Stockholm's Norra Linken project in Sweden. This method is currently being used in the excavation of the Stockholm bypass. In the method, grout-hole drilling is initiated with the drilling of every second grout hole. MWD data are extracted and supplied to the engineering geologist. These data are analysed, and the need for additional drill holes is established. The decision should be made before the remaining grout holes are drilled.

Schunnesson et al. (2011) established a water index based on normalized water flow and normalized water pressure. Both high water index and low water index can be used to determine the location of fractures, based on water ingress and outflow at the drill hole. Rødseth (2013) showed a moderate to good correlation between the MWD parameters and the RQD value in the Eikrem, Løren and Oppdølstranda tunnels in Norway. On the other hand, there was only a weak correlation between the MWD parameters and the degree of fracturing (RQD divided by the joint number, $J_{\mathrm{n}}$, extracted with the $Q$ system). Ghosh et al. (2017) found fracturing observed with a drill-hole camera correlated strongly with variations in the penetration rate and rotation pressure in the drilling of sublevel caving blast holes in the Kirunavaara mine; using this method, they could predict blast-hole chargeability. Van Eldert et al. (2020a) showed the Epiroc fracture index could portray geological structures of the rock mass at two ramp tunnels at the Stockholm bypass. The study found both grout holes and blast holes gave a reliable portrayal of the rock mass structures.

Although rock mass characterization is well investigated, a quantitative method of using MWD technology in tunnelling practice has not been established. Therefore, this paper aims to relate MWD parameters to the rock mass quality and rock support to provide a quantitative method. It proposes and tests the use of numerical relations - multilinear regression and the Levenberg-Marquardt method - and a holistic visual presentation of MWD data to characterize rock mass and predict rock mass support requirements.

\section{Case study: Stockholm bypass}

The Stockholm bypass is one of the largest ongoing tunnelling projects in Scandinavia today. The purpose of the construction project is to improve the North-South links in the Stockholm area. The project includes the excavation of $18-\mathrm{km}$ doubletube, triple-lane tunnels (Trafikverket 2018). In addition, access and support tunnels are excavated at a length of up to an additional $20.6-\mathrm{km}$. At its deepest point, the main tube will be located 60-m underneath Mälaren waterway, $100 \mathrm{~m}$ below the surface. The tunnels are excavated by the drill and blast method and supported by sprayed concrete liner and rock bolts. Ahead of the face, pre-grouting with 18 - to 30 -m-long boreholes is performed each third or fourth blasting round, and in some cases more often. In general, the blast rounds are excavated in $5.0-$ to $6.0-\mathrm{m}$ sections.

This study concentrates on the drilling data from one main tunnel excavated by Subterra AB, at the southern end of the Stockholm bypass between Skärholmen and Sätra (see Fig. 1). The tunnel in question is the northern part of Tunnel 201, the eastern main tunnel, between sections 11629 and 12495. The rock mass in this part of the tunnelling project consists mainly of grey, medium to large grained gneiss (Arghe 2016). Lightly foliated granite, pegmatite intrusions, and greenstone veins have been indicated in the site investigation as well. Outcrops of exposed oxidized and weathered rock masses were observed and these have caused excavation stability issues during the tunnel excavation previously.

At the Stockholm bypass, the rock quality was determined during the site investigation and classified initially in five classes (see Table 1). These values are displayed in Appendix Table 7. The rock mass support is determined based on the rock class derived from the $Q$-value. Each rock class has a predefined bolt spacing, bolt length and sprayed concrete thickness. The rock support for the main tunnel width in this study (12-m to $17-\mathrm{m})$ is displayed in Table 2.
Fig. 1 Measurement while drilling data collected at the southern part of the Stockholm bypass, with the tunnel number. The colour scheme is based on tunnel elevation below sea level

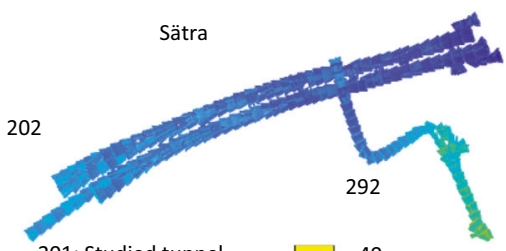

201: Studied tunnel

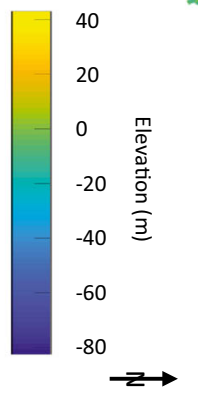


Table 1 Rock classes and $Q$-value applied for the rock mass classification at the Stockholm Bypass (after Arghe 2016)

\begin{tabular}{|c|c|c|c|}
\hline $\begin{array}{l}\text { Rock } \\
\text { class }\end{array}$ & $Q$-value & $\begin{array}{l}\text { Rock } \\
\text { quality }\end{array}$ & Description of rock mass \\
\hline I & $Q>10$ & $\begin{array}{l}\text { Very } \\
\text { good }\end{array}$ & $\begin{array}{l}\text { Sparsely fractured or large blocky granite, gneiss-granite, pegmatite or occasionally slaty gneiss. Mainly rough } \\
\text { fracture surfaces with no or little fracture filling. Average block edge length }>2-\mathrm{m} \text {. Three or fewer fracture sets. }\end{array}$ \\
\hline II & $4<Q \leq 10$ & Good & $\begin{array}{l}\text { Large or medium blocky granite, gneiss-granite, pegmatite or moderate slaty gneiss. Mainly rough fracture surface } \\
\text { with little fracture filling. Average block edge length } 0.6-2-\mathrm{m} \text {. Three or more fracture sets. }\end{array}$ \\
\hline III & $1<Q \leq 4$ & Fair & $\begin{array}{l}\text { Medium to small blocky granite, gneiss-granite pegmatite or slaty gneiss. Fracture surfaces are rough to smooth, with } \\
\text { moderate fracture filling. Average block edge length of } 0.2-0.6-\mathrm{m} \text {. }\end{array}$ \\
\hline IV & $0.1<Q \leq 1$ & Poor & $\begin{array}{l}\text { Small blocky to crushed, metamorphic granitic rock mass or heavily slated gneiss with mineral-filled fractures. } \\
\text { Average block edge length }<0.2-\mathrm{m} \text {. }\end{array}$ \\
\hline V & $Q \leq 0.1$ & $\begin{array}{l}\text { Very } \\
\text { poor }\end{array}$ & $\begin{array}{l}\text { Tectonically heavily affected, disjointed rock mass, fracture and crush zones. Mainly smooth, polished fracture } \\
\text { surfaces filled with large amounts of soft minerals. }\end{array}$ \\
\hline
\end{tabular}

\section{Methodology}

\section{Measurement while drilling data}

The MWD data were collected by five Atlas Copco WE3 boomers, each equipped with three COP3038 drill hammers. The drill rigs were in pristine condition and fully equipped with state-of-the-art MWD capabilities. The drilling data were collected from $<30$-m-long grout holes. The measurement interval was set to record values at $2-\mathrm{cm}$ intervals; in practice, the samples were taken between 2- and 3-cm intervals depending on the penetration rate because of the limited sampling frequency of the data logging system, which has a maximum sampling rate of 2.5-Hz (Atlas Copco 2009). The logging equipment kept track of hole depth, penetration rate $(P R)$, percussive pressure $(P P)$, feed pressure $(F P)$, damping pressure $(D P)$, rotation speed $(R S)$, rotation pressure $(R P)$, water flow $(W F)$ and water pressure $(W P)$ during drilling. Based on the known rig location and the placement of the drilling booms, the MWD samples were projected in 3D space based on the drill-hole collar orientation (Navarro et al. 2018). The recorded MWD parameters were filtered by excluding data points at the drill-hole collar and rod coupling (Van Eldert et al. 2020b). Then, the data was normalized for the drill-hole length, feed pressure and rotation pressure according to Schunnesson (1998) for each extension rod separately (Van Eldert et al. 2020b). Lastly, the outliers of the normalized MWD data were removed. The data ranges of the normalized and filtered MWD data are displayed in Table 3. The distribution of MWD values was calculated with MATLAB R2018b for each 1-m section on the left wall, left haunch, left roof, right roof, right haunch and right wall. The MWD data from the floor were excluded, as no additional data were available on the rock mass quality or support of the tunnel floor. This division into sections or blocks is shown in Fig. 2. For each block along Tunnel 201, the average scaled absolute residuals were calculated using Eq. 1 .

$\mathrm{MWD}_{\text {scaled residual }}=\frac{1}{n} \sum_{i=1}^{n}\left|\frac{\mathrm{MWD}_{n}-\overline{\mathrm{MWD}}_{\text {block }}}{\sqrt{\sigma_{\mathrm{MWD}^{2}}}}\right|$

where:

$\begin{array}{ll}\mathrm{MWD}_{\text {scaled }} & \text { the scaled MWD residual } \\ \text { residual } & \\ n & \text { the number of samples in block } \\ \mathrm{MWD}_{n} & \text { the samples' MWD value }\end{array}$

Table 2 Rock support for Stockholm bypass tunnel width 12-m to 17-m

\begin{tabular}{|c|c|c|c|c|c|c|c|c|}
\hline \multirow[t]{3}{*}{ Rock class } & \multirow[t]{3}{*}{ Rock quality } & \multicolumn{4}{|l|}{ Bolt } & \multirow{2}{*}{\multicolumn{2}{|c|}{ Sprayed concrete thickness (mm) }} & \multirow[t]{3}{*}{ Decision yea } \\
\hline & & \multicolumn{2}{|l|}{ Spacing (m) } & \multicolumn{2}{|l|}{ Length (m) } & & & \\
\hline & & Roof/haunch & Wall & Roof/haunch & Wall & Roof/haunch & Wall & \\
\hline I & $Q>10$ & Selective (1.5) & Selective (1.5) & 4 & 4 & 50 & 0 & 2014 \\
\hline II & $4<Q \leq 10$ & 2.0 & Selective (1.5) & 4 & 4 & 50 & 0 & 2014 \\
\hline III & $1<Q \leq 4$ & 1.7 & 1.7 & 4 & 4 & 75 & 50 & 2014 \\
\hline IV & $0.1<Q \leq 1$ & 1.5 & 1.5 & 4 & 4 & 75 & 50 & 2014 \\
\hline $\mathrm{V}$ & $0.01<Q \leq 0.1$ & 1.5 & 1.5 & 5 & 5 & 200 & 200 & 2017 \\
\hline VI & $Q \leq 0.01$ & \multicolumn{4}{|c|}{ Individual assessment } & & & 2017 \\
\hline
\end{tabular}


Table 3 The maximum, mean, median, minimum of the normalized and filtered MWD values collected in Tunnel 201. The filtering removed the sample points from the collaring and coupling processes. Besides, unrealistic values were removed from the original data set

\begin{tabular}{|c|c|c|c|c|c|c|c|c|}
\hline $\begin{array}{l}\text { MWD } \\
\text { parameter }\end{array}$ & $\begin{array}{l}\text { Penetration rate } \\
(\mathrm{m} / \mathrm{min})\end{array}$ & $\begin{array}{l}\text { Percussive } \\
\text { pressure (bar) }\end{array}$ & $\begin{array}{l}\text { Feed } \\
\text { pressure } \\
\text { (bar) }\end{array}$ & $\begin{array}{l}\text { Damping } \\
\text { pressure (bar) }\end{array}$ & $\begin{array}{l}\text { Rotation speed } \\
(\mathrm{rpm})\end{array}$ & $\begin{array}{l}\text { Rotation } \\
\text { pressure (bar) }\end{array}$ & $\begin{array}{l}\text { Water flow } \\
\text { (L/min) }\end{array}$ & $\begin{array}{l}\text { Water } \\
\text { pressure (bar) }\end{array}$ \\
\hline Maximum & 3.89 & 178 & 66.9 & 73.8 & 495 & 80.9 & 207 & 44.9 \\
\hline Mean & 1.74 & 147 & 38.8 & 47.2 & 288 & 56.2 & 176 & 22.9 \\
\hline Median & 1.73 & 151 & 40.7 & 46.4 & 289 & 56.6 & 177 & 23.4 \\
\hline Minimum & 0 & 0 & 0 & 0 & 0 & 4.4 & 0 & 0 \\
\hline
\end{tabular}

$\mathrm{MWD}_{\text {block }}$ $\sigma_{\mathrm{MWD}}^{2}$

the mean MWD value in each block the standard deviation of the MWD parameter in each block

\section{Tunnel mapping and support requirements}

Geological mapping was performed by several geologists from $\AA$ F from 2016 to 2018 (ÅF 2016-2018). The mapping included documentation of geological structures and a description of the rock mass, with the $Q$-system (Barton et al. 1974) used to extract the $Q$-values (Eq. 2) and the $Q_{\text {base-values }}$ (Eq. 3) for each tunnel section. These $Q$-values were used to establish the rock support requirements for the tunnel. For this study, these values were separated into six blocks similar to the MWD data (after Barton et al. 1974).

$Q=\frac{\mathrm{RQD}}{J_{\mathrm{n}}} \times \frac{J_{\mathrm{r}}}{J_{\mathrm{a}}} \times \frac{J_{\mathrm{w}}}{\mathrm{SRF}}($ Barton et al.1974)

$Q_{\text {base }}=\frac{\mathrm{RQD}}{J_{\mathrm{n}}} \times \frac{J_{\mathrm{r}}}{J_{\mathrm{a}}}($ after Barton et al.1974)

where:

RQD the rock quality designation

$J_{\mathrm{n}} \quad$ the joint set number

$\mathrm{J}_{\mathrm{r}} \quad$ the joint roughness number

$J_{\mathrm{a}} \quad$ the joint alteration number

$J_{\mathrm{w}} \quad$ the joint water number

SRF the stress reduction factor

\section{Analysis of combined data}

The collected MWD data were correlated to the rock mass characteristics and support using multilinear regression (MLR) and the Levenberg-Marquardt (LM) method. The mean and residual values of the MWD parameters were analysed for their correlation to the actual $Q$-value, RQD, $\mathrm{RQD} / \mathrm{Jn}$, sprayed concrete thickness and bolt spacing at the tunnel walls, haunches and roof. Both the MLR and LM methods are iterative and aim to obtain the optimum fit. MLR determines weights for the linear parameters to achieve this fit. The LM method is a robust method for ill-conditioned, rank-deficient linear least-squares sub-problems or nonlinear least-square problems (Heath 2002). It assigns linear and power coefficients to each parameter. Based on previous geotechnical studies, $|R|>0.5$ is considered a strong correlation, and $0.5>|R|>0.3$ is a moderate to weak correlation (Cesano et al. 2000; Rødseth 2013). Both MLR and LM methods have been employed for MWD investigations: the MLR to estimate the extent of blasting damage (Van Eldert et al. 2018) and the LM to determine over-break (Navarro et al. 2018) in tunnelling. Lastly, in this study, a visual holistic comparison was applied to investigate the predictive capabilities of MWD parameters for rock mass support requirements.

\section{Results and discussion}

\section{MWD parameter residuals' distributions}

The scaled penetration rate residuals of the blocks in the tunnel are displayed in Fig. 3; these residuals were calculated with Eq. 1 and are dimensionless. The distribution of these scaled residuals is semi-normal, skewed towards zero. The distributions of the penetration rate residuals are similar in the tunnel roof, haunches and walls of each tunnel section; the medians are at 0.80 . In Fig. 4 , the distributions of the

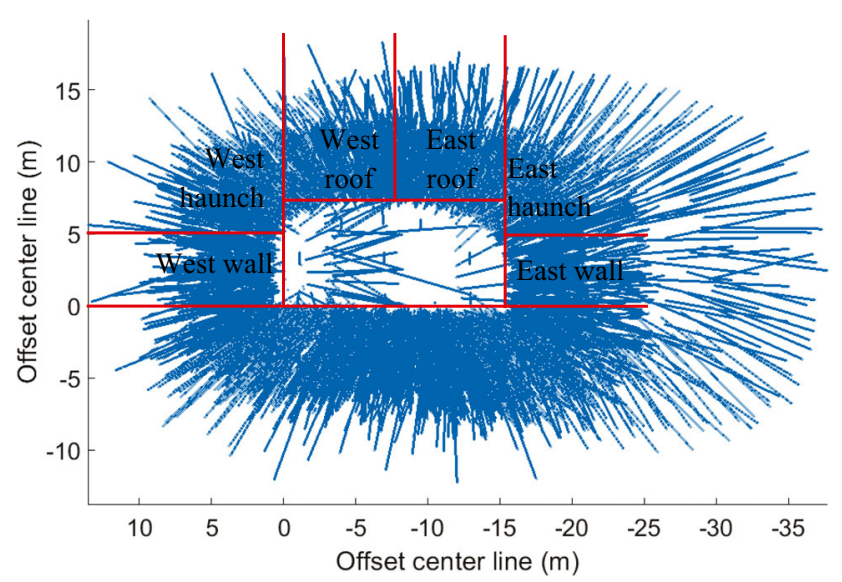

Fig. 2 Separation of the tunnel areas for every 1-m section, $x$-axis reverse because of the driving direction 
Fig. 3 Normalized penetration rate residuals of the blocks along Tunnel 201. The distribution of the residuals is semi-normal, skewed towards zero
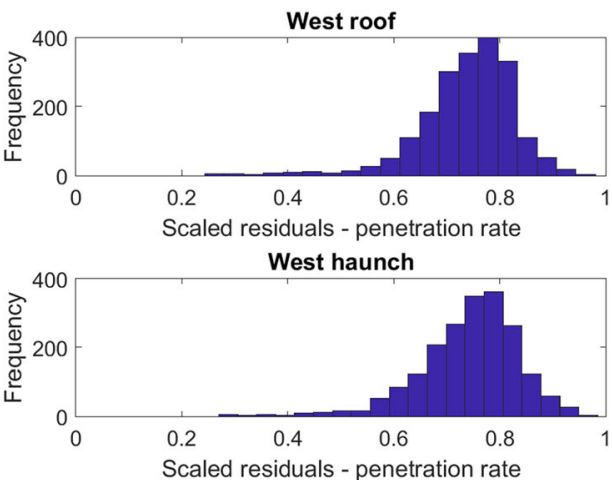

West wall

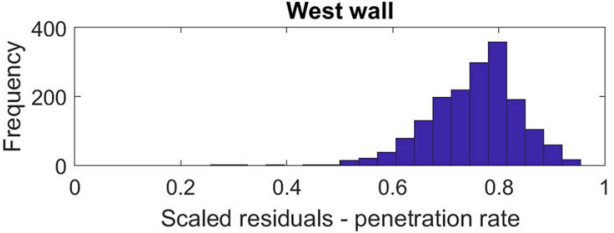

East roof

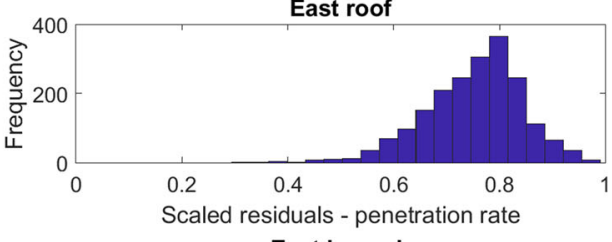

East haunch

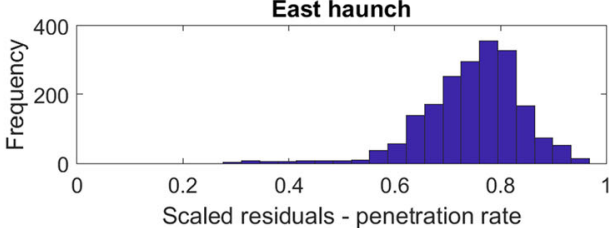

East wall

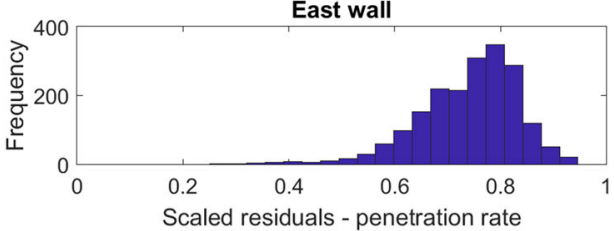

rotation pressure residuals show a similar semi-normal distribution for all the tunnel sections. Also, these residuals are dimensionless. The median values for the rotation pressure distributions are at 0.78 . A high value of the residuals implies a large deviation of the mean block value; this indicates a variable rock mass and, thus, extensive fracturing at the block's location.

\section{Actual Q-values' distributions}

During excavation, geotechnical mapping was performed at each tunnel section. For the study, the values of the $Q$-system were mapped for the walls and roof separately. The values recorded for the $J_{\mathrm{n}}$ (joint set number), $J_{\mathrm{r}}$ (joint roughness number), $J_{\mathrm{a}}$ (joint alteration number), $J_{\mathrm{w}}$ (joint water reduction factor) and SRF (stress reduction factor) were not recorded on a continuous scale; rather, the values are established in the $Q$ - system, and these values are incremental. The RQD value describes the fracturing of the rock mass. The $Q$-system recommends the use of RQD-intervals of 5\% (NGI 2015). The collected RQD values in Tunnel 201 show that, in practice, most recordings were taken at $10 \%$ intervals (see Fig. 5). A semi-normal distribution is expected, but $5 \%$ intervals (e.g. $55 \%$ or $65 \%$ ) were less frequently recorded. The quality of the extracted data depends on the subjectivity, precision and accuracy of the geologists performing the mapping. Taking this into account, the RQD values are semi-normal distributed, and their distributions correspond well with the distributions of the calculated residuals of the penetration rate and the rotation pressure in Figs. 3 and 4. The observations made from the RQD data and the nature of the other parameters are noticeable in the actual $Q_{\text {base-values (Fig. 6) and the } Q \text {-values }}$ (Fig. 7), as the distributions of the input parameters, result in their intermittent distribution.
Fig. 4 Normalized rotation pressure residuals of the blocks along Tunnel 201. The distribution of the residuals is semi-normal, skewed towards zero
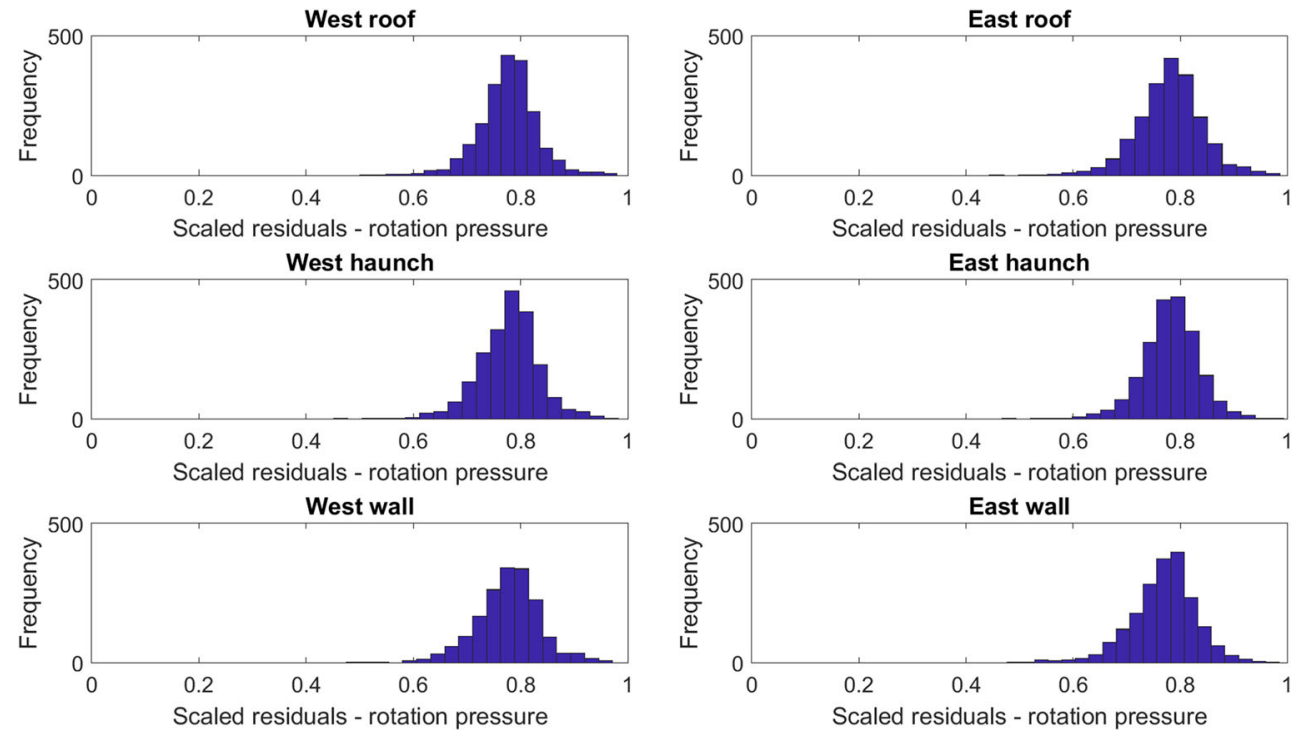

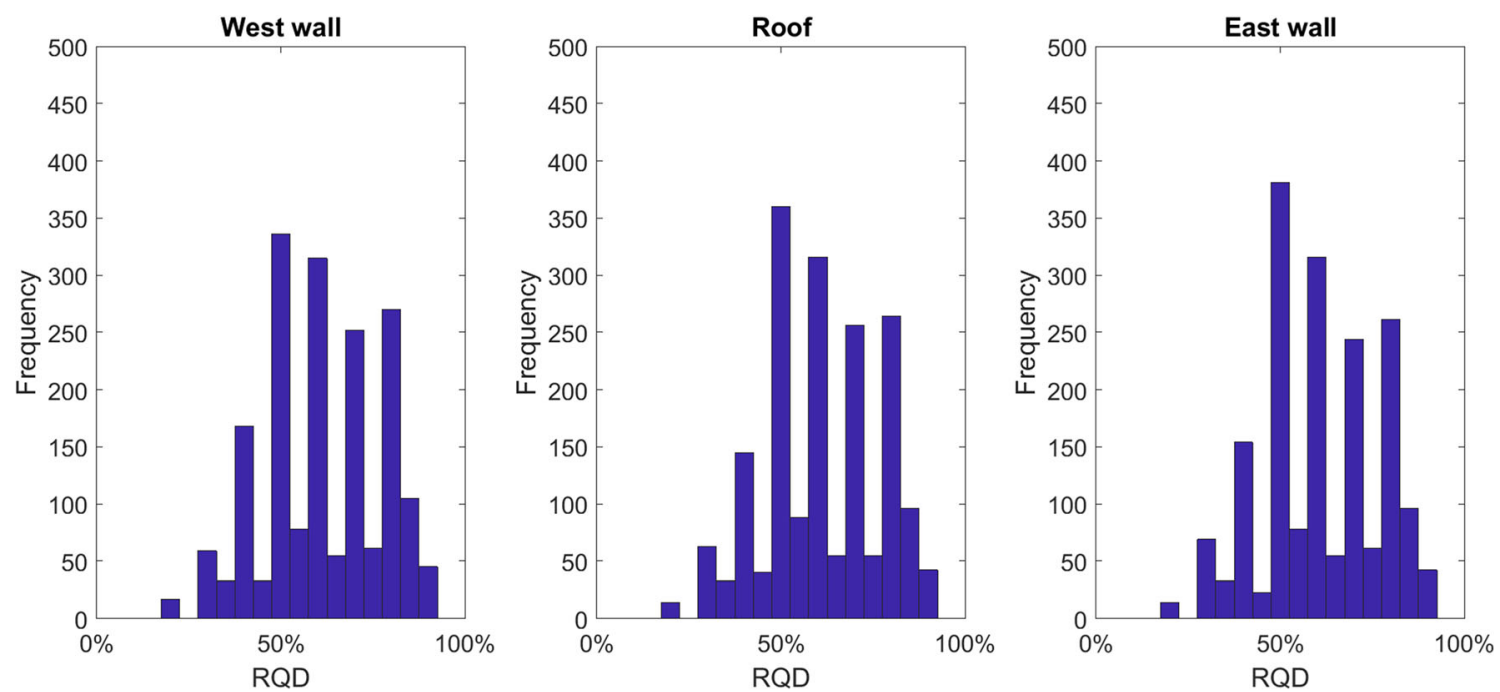

Fig. 5 a-c Distribution of the observed RQD values in Tunnel 201, for the tunnel walls and roof

\section{Rock support}

Based on the actual $Q$-values along the tunnel, as well as the rock mass quality and support requirements determined during the site investigation, an updated rock support plan was provided by the engineering geologist. The predetermined values were then verified and updated with the observations during each mapping round. The distribution of the sprayed concrete (shotcrete) along the tunnel is shown in Fig. 8. The data show limited sprayed concrete increments, with thicknesses of $0-\mathrm{mm}, 50-\mathrm{mm}, 75-\mathrm{mm}, 100-\mathrm{mm}, 150-\mathrm{mm}$ and 200-mm. In some sections, a combination of these thicknesses was used, for example, 50-mm on top of cracked 75-mm sprayed concrete $(125-\mathrm{mm})$, or locally thicker sprayed concrete in the roof, haunches or walls. The distributions of the sprayed concrete are similar for the roof (both east and west) and the haunches. The sprayed concrete on the tunnel walls is significantly less thick than on the roof and haunches. The most common thickness of sprayed concrete in the roof and haunches was $75-\mathrm{mm}$ and on the tunnel walls $50-\mathrm{mm}$. The differences in ground support for the tunnel roof and walls are described in the $Q$-system manual. NGI (2015) states that to determine the rock support for intermediate quality rock masses, the $Q$-value in the walls should be multiplied by a factor of 2.5.

The distribution for the bolt spacing was also investigated, with a numerical limit of 3-m bolt spacing set for selective (spot) bolting. The distributions show limited bolt-spacing increments: $1.25-\mathrm{m}, 1.5-\mathrm{m}, 1.7-\mathrm{m}$ and $2.0-\mathrm{m}$ for the roof, haunches and walls (Fig. 9). The rock support distributions for the roof and haunches show in general, slightly less rock supported then in the two tunnel walls, as advised in NGI (2015). The median bolt spacing for the roof, haunches and walls is $1.5-\mathrm{m}$.
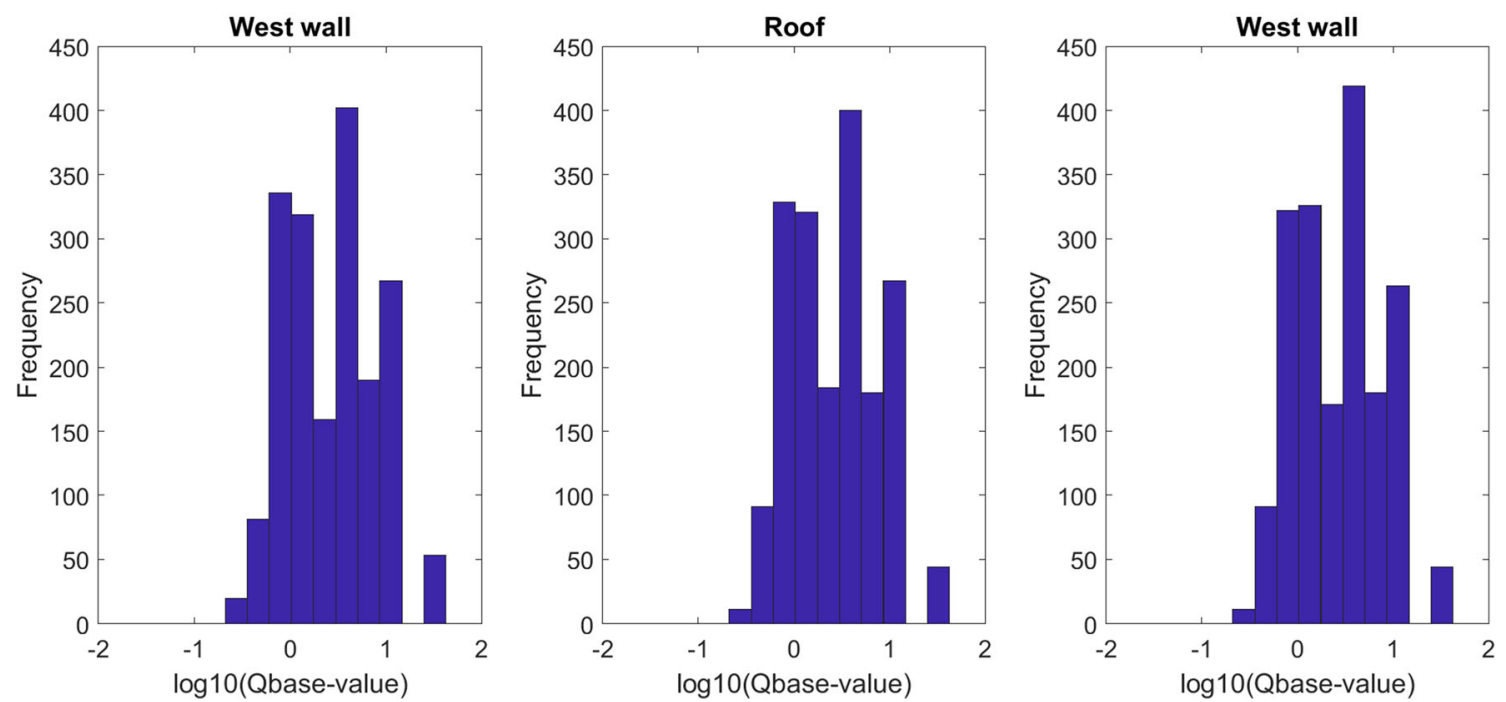

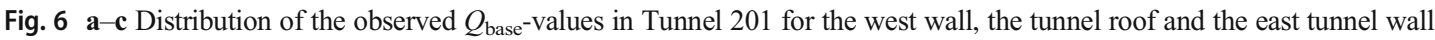



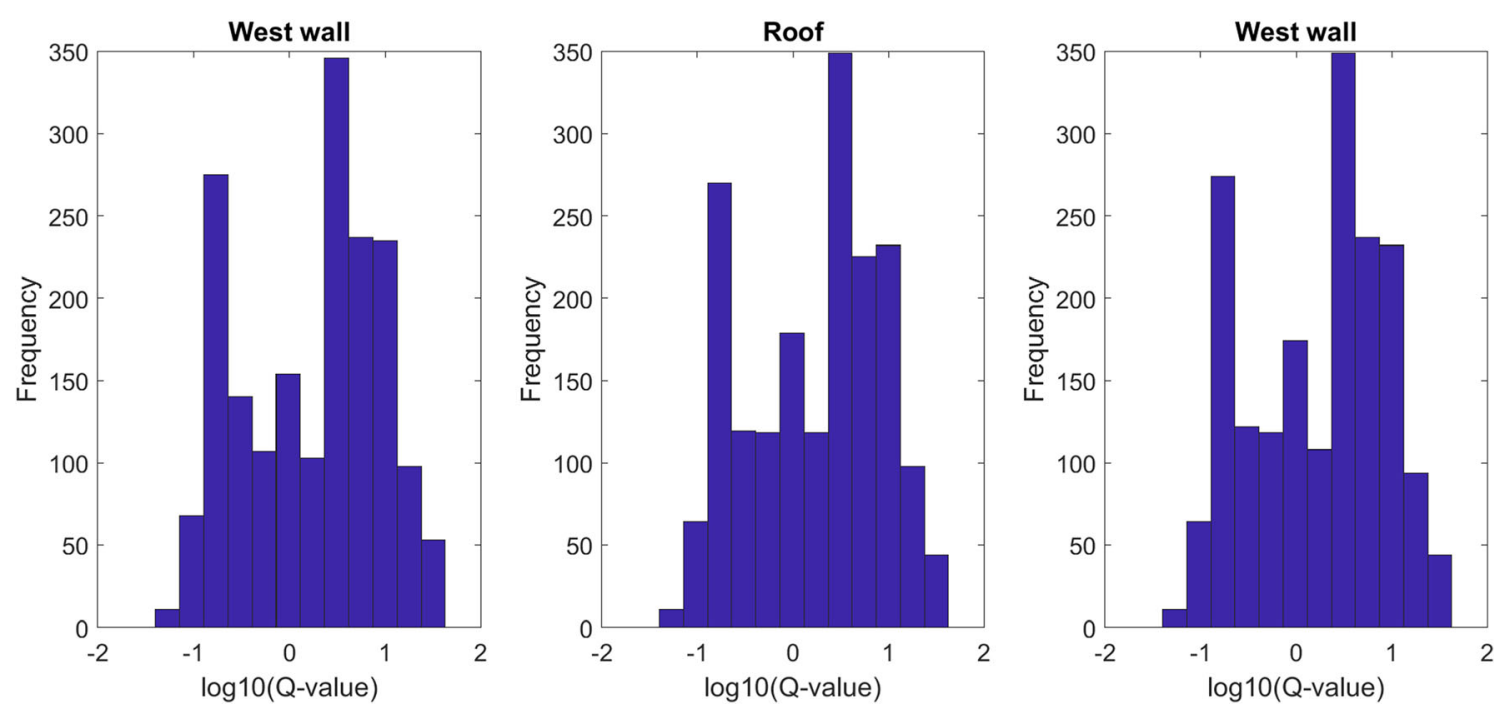

Fig. 7 a-c Distribution of the observed $Q$-values for the west wall, the tunnel roof and the east tunnel wall in Tunnel 201 of the Stockholm bypass

\section{Numerical comparison between MWD, Q-values and rock support}

Previous studies found the fracture density (extent of fracturing) and rock mass quality can be portrayed by a combination of normalized penetration rate, normalized rotation pressure and normalized water flow and normalized water pressure (Schunnesson 1996; Rødseth 2013; Martinsson and Bengtsson 2010; Ghosh et al. 2017). In this study, multilinear regression and Levenberg-Marquardt methods were applied to correlate and predict the rock mass quality and rock support requirements.

\section{Multilinear regression}

In this study, both the mean (Table 4) and the residual of these parameters were used in the multilinear regression analysis to determine their correlation with the rock mass characteristics. The mean MWD values correlate strongly with the $Q_{\text {base }}$-value and $Q$-value in the roof $(R: \sim 0.5)$ and to a weaker extent in the haunches and walls $(0.3<R<0.4)$. Also, there is a weak correlation between RQD and MWD; RQD $/ J_{\mathrm{n}}$ and MWD; and bolt spacing and MWD $(\sim 0.3<R<\sim 0.4)$, as displayed in Table 4. These results are in line with the correlations found by Rødseth (2013). For the MWD residuals, the MLR analysis shows no significant linear correlation with the $Q$-system parameters and rock support installed. The general low correlation between the rock mass condition and MWD data might be caused by bias in the collected data; the $Q$-value and its parameters are based on observation, and the MWD samples are measured values. In addition, the data of RQD, $J_{\mathrm{n}}$, sprayed concrete and bolt spacing are incrementally distributed, whereas the MWD parameters are
Fig. 8 Distribution of the advised sprayed concrete thickness in Tunnel 201 for the west wall, the west haunch, the tunnel roof (west and east), the east haunch and the east tunnel wall. The sprayed concrete was only applied to the tunnel perimeter in certain thicknesses: 0-mm, 50-mm, 75$\mathrm{mm}, 100-\mathrm{mm}, 150-\mathrm{mm}$ and 200$\mathrm{mm}$
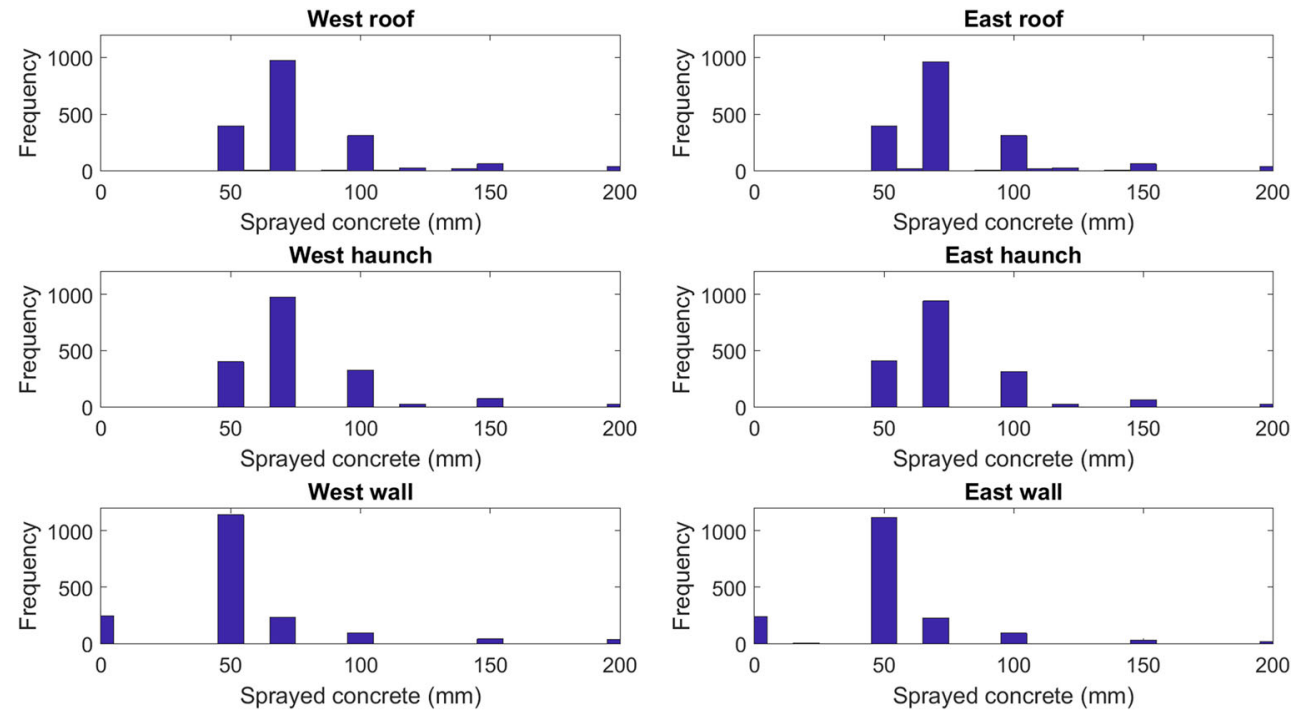
Fig. 9 Distribution of the advised bolt spacing in Tunnel 201 for the west tunnel wall, the west haunch, the tunnel roof (west and east), the east haunch and the east tunnel wall. The bolts were spaced along the tunnel perimeter at certain distances: $1.25-\mathrm{m}, 1.5-\mathrm{m}, 1.7-\mathrm{m}$, 2.0-m or selective (spot) bolting $(\sim 3-\mathrm{m})$
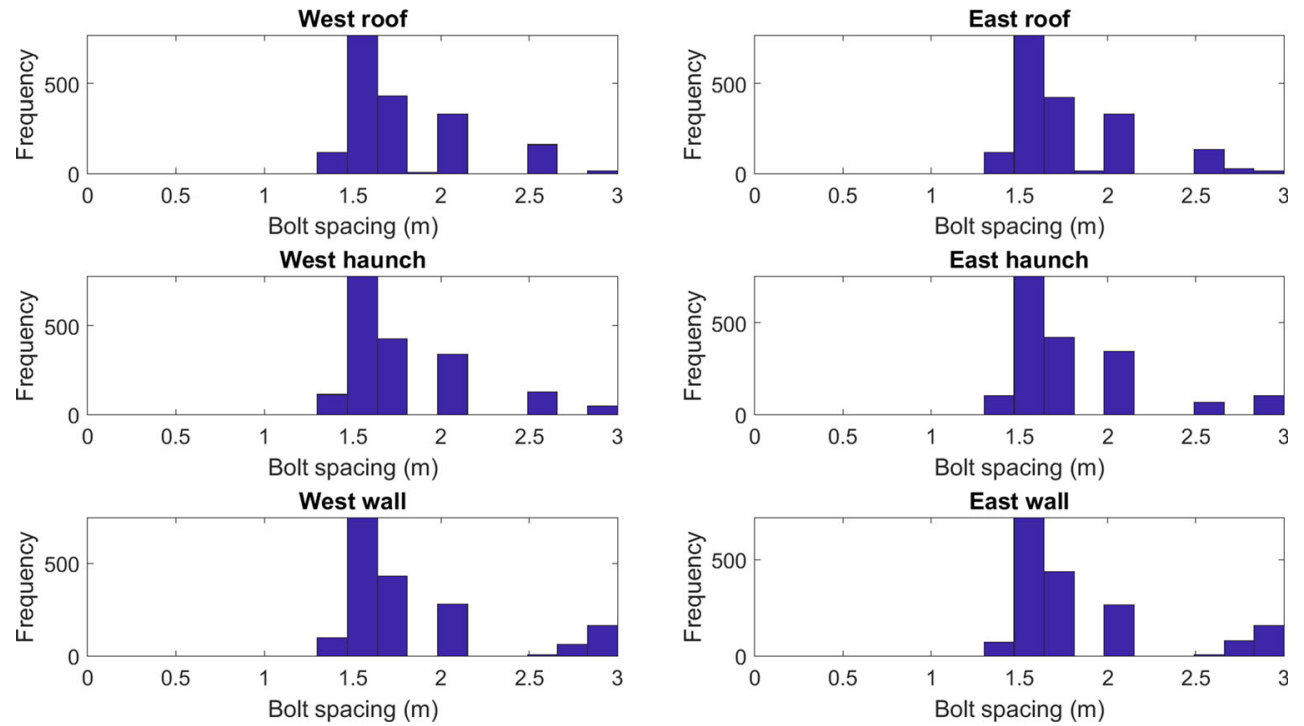

recorded continuously. This causes an additional observation error and bias in the collected data.

\section{Levenberg-Marquardt method}

The Levenberg-Marquardt method was used to predict the

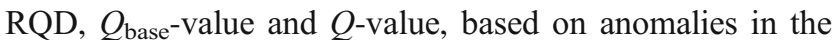
residuals of penetration rate and rotation pressure, water flow and water pressure at the six blocks along Tunnel 201 (see Eq. 4). The results of the prediction of the RQD are shown in Fig. 10 , both in $5 \%$ and $10 \%$ increments. The figure indicates a large discrepancy between the observed values and the predicted values. The low RQD values are overestimated in the prediction, and the high RQD values are underestimated in the prediction. The narrow range of predicted RQD values may be caused by the limited number of MWD values; these values include very high and low residuals. Also, the observed RQD values may contain inaccuracies; they are based on the observations of the engineering geologist, not on measured data.
Although imprecise, the predicted RQD-observed RQD plots show a clear trend in the data. The predictions of $\log \left(Q_{\text {base }}\right)$ and $\log (Q)$ were investigated in with the same method and showed similar results as the RQD values; low $Q$-values are overestimated and high $Q$-values are underestimated in the prediction, as displayed in Fig. 11. Lastly, the LevenbergMarquardt method was used to predict the rock support requirements based on the residual MWD parameters (Fig. 12). The predicted rock support data show a large data range (Fig. 12). The over- and underestimations of the installed bolt spacing and sprayed concrete thickness are very similar to those noted for the RQD and $Q$-values. The findings show the difficulty of numerically correlating MWD values with rock mass properties and rock support requirements.

$$
\begin{aligned}
\mathrm{PV}= & x_{1}+x_{2} \times \mathrm{PR}_{\mathrm{R}}^{x_{3}}+x_{4} \times \mathrm{RP}_{\mathrm{R}}^{x_{5}}+x_{6} \times \mathrm{WF}_{\mathrm{R}}^{x_{7}} \\
& +x_{8} \times \mathrm{WP}_{\mathrm{R}}^{x_{9}}
\end{aligned}
$$

collected along Tunnel 201 and the $Q$-system parameters (RQD and $\left.J_{\mathrm{n}}\right)$, and the installed rock support in the tunnel for the tunnel walls, haunches and roof
Table 4 Coefficient of determination $(R)$ for the mean normalized penetration rate, mean normalized rotation pressure, mean normalized

\begin{tabular}{|c|c|c|c|c|c|c|}
\hline Mean: $R$ & West wall & West haunch & West roof & East roof & East haunch & East wall \\
\hline RQD-MWD & 0.22 & - & 0.32 & 0.14 & 0.26 & 0.00 \\
\hline$J_{\mathrm{n}}-\mathrm{MWD}$ & - & - & - & - & - & - \\
\hline $\mathrm{RQD} / J_{\mathrm{n}}-\mathrm{MWD}$ & 0.26 & 0.32 & 0.44 & 0.41 & 0.24 & 0.30 \\
\hline$Q_{\text {base-value-MWD }}$ & 0.30 & 0.42 & 0.51 & 0.51 & 0.32 & 0.35 \\
\hline$Q$-value-MWD & 0.32 & 0.42 & 0.50 & 0.50 & 0.36 & 0.35 \\
\hline Sprayed concrete thickness-MWD & 0.26 & - & - & - & - & - \\
\hline Bolt spacing-MWD & 0.36 & - & 0.36 & 0.14 & 0.32 & 0.33 \\
\hline
\end{tabular}
water flow and mean normalized water pressure from the MWD data 

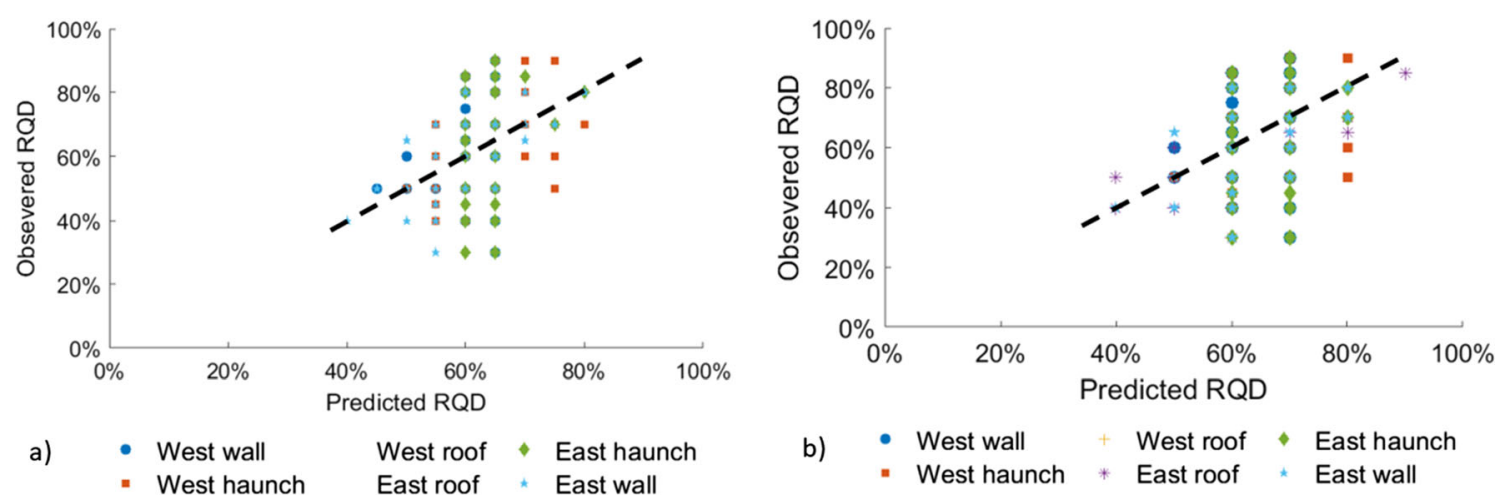

Fig. 10 Predicted and observed RQD values in Tunnel 201, in (a) 5\% and (b) $10 \%$ intervals

PV the predicted value

$\mathrm{PR}_{\mathrm{R}} \quad$ the residual penetration rate

$\mathrm{RP}_{\mathrm{R}} \quad$ the residual rotation pressure

$\mathrm{WF}_{\mathrm{R}}$ the residual water flow

$\mathrm{WP}_{\mathrm{R}}$ the residual water pressure

$x_{1}$ to $x_{9}$ the assigned constants

\section{Holistic visual interpretation}

The findings show the MWD parameters are weakly correlated to the RQD, $Q$-values and rock support. Therefore, the rock support requirements cannot be predicted precisely with MLR and LM methods. To incorporate this uncertainty and limited data quality, a holistic, visual comparison was performed.

\section{Normalized MWD data versus RQD and $Q_{\text {base }}$-value}

First, a comparison was made between (a) penetration rate, (b) rotation pressure, (c) water pressure, (d) Epiroc's fracture index, (e) Ghosh et al. (2017)'s fracture index, (f) penetration rate and rotation pressure combined (fracture index), (g) water index in the tunnel roof and the $Q_{\text {base-value. Figure } 13 \text { shows }}$ the behaviour of the normalized MWD parameters and their calculated indices. The figure aims to correlate MWD parameters to each other and the rock mass quality ( $Q_{\text {base-value). }}$. Also, the figure highlights parameters and indices which have a strong correlation to the rock mass quality. Figure $13 \mathrm{a}-\mathrm{g}$ show the visual representation of the MWD data in the roof of Tunnel 201 from section 11700 to 11800 , for five grouting fans. These grouting fans stretch from 11791 to 11764,11770 to 11743,11748 to 11721,11728 to 11701 and 11705 to 11678 , with a \pm 5 -m overlap. Figure $13 \mathrm{~h}$ shows the mapped $Q_{\text {base-values along the tunnel roof. The normalized penetra- }}$ tion rate in Fig. 13a indicates a higher drilling rate in tunnel sections 11708 to 11746 , indicating better drillability and, thus, a weaker rock mass. This is also indicated by the increased normalized rotation pressure (Fig. 13b) and, to a lesser extent, the lower normalized water pressure (Fig. 13c). The higher normalized penetration rate, higher normalized rotation pressure and lower normalized water pressure are not equally distributed along the tunnel roof (Fig. 13a-c). This heterogeneity along the roof in the MWD data is often not recorded during the geotechnical mapping, as only one $Q$-value is determined for the roof. Figure 13d shows Epiroc's fracture index; here, several bands of a lower fracture index are indicated. These bands occur at regular 20-m to $23-\mathrm{m}$ intervals and correspond well with the collaring of the grout holes. These discrepancies reflect the nature of the drilling process; the drill-hole collar is drilled more carefully, significantly influencing the MWD data. Besides, the drilling process may be influenced by the excavation damage zone at the tunnel face and perimeter where the grout-hole drilling is initiated. These lower values in Epiroc's fracture index are an inherent feature of the unfiltered collar data. Although the index is obscured, the previously determined fractured area in sections 11700 to 11745 is apparent. This same fractured area is
Fig. 11 Predicted and observed $Q$-values in Tunnel 201, both $Q_{\text {base }}$ (a) and $Q$-value (b) on a $\log$ $\log$ scale
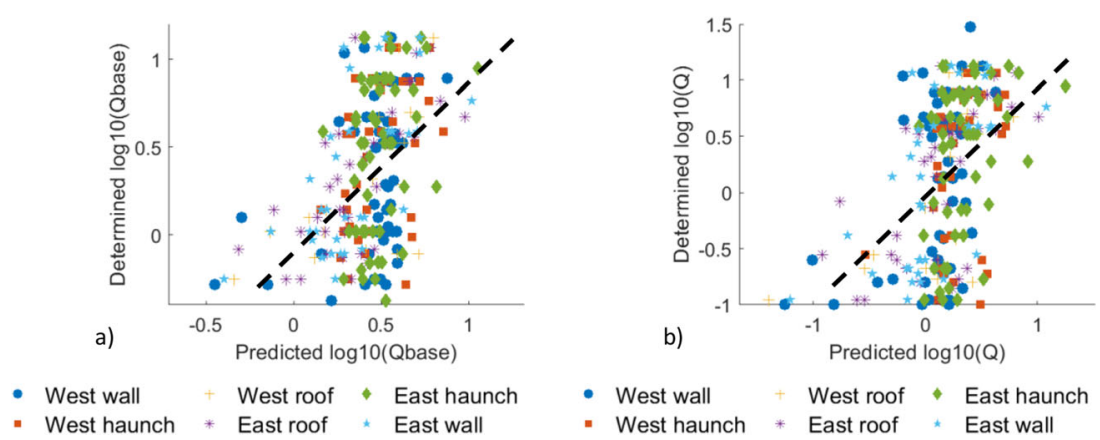
Fig. 12 Predicted and advised incremental rock support, both bolt spacing (a) and sprayed concrete thickness (b), in Tunnel 201

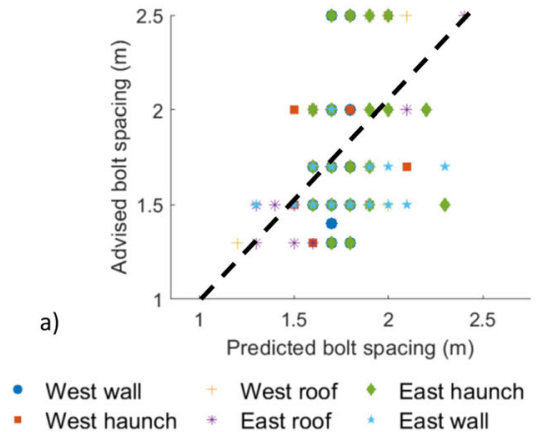

b)

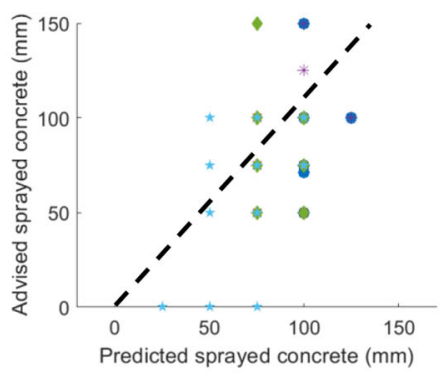

- West wall

- West haunch
West roof East haunch

East roof * East wall portrayed in the fracture index defined by Ghosh et al. (2017) in Fig. 13e. In Figure 13f, the normalized penetration rate (drillability) and normalized rotation pressure (torque) are weighted three to one. The selection of these MWD parameters is based on the relationship with the fracture density established by Schunnesson $(1996,1998)$ and Ghosh et al. (2017). An iterative process was performed to maximize the contrast between the fractured and unfractured areas in the MWD results. Figure $13 \mathrm{~g}$ shows the distribution of the water index in the tunnel. In this case study, this particular index does not show a clear contrast for the degree of fracturing and, thus, is not applicable as an indicator of rock mass quality. Figure $13 \mathrm{~h}$ shows the $Q_{\text {base-values along the tunnel roof. The }}$ $Q_{\text {base-values increase after section } 11742 \text {, coinciding with the }}$ registered increased fracture density in the MWD data.

The holistic visual approach indicates areas of less competent, fractured rock mass. The same areas are established with the actual $Q$-values. The combined penetration rate and rotation residuals displayed in Fig. $13 \mathrm{f}$ are plotted against the observed RQD (a) and $Q_{\text {base-values (b) in the }}$ tunnel roof in Fig. 14. Both the RQD- and the $Q_{\text {base-values }}$ show a good correlation with the weighted normalized penetration rate and rotation pressure; more fractured rock (higher fracture index) has a lower RQD and $Q_{\text {base-value. }}$ The approach provides a good image of the rock mass characteristics (fracturing) and is in line with the results obtained using Epiroc's Underground Manager (Van Eldert et al. 2020a).

\section{Normalized MWD data versus geotechnical mapping}

Figure 15 compares the tunnel mapping with the MWD data in the tunnel roof. The mapping of the tunnel identifies six fractured areas, numbered I-VI in Fig. 15 and described in Table 5. These structures can also be observed in the MWD fracture index. The first structure in this part of the tunnel is observed around section 11710, marked as fracture area I. This fracture area was seen in both the mapping and the MWD data (Table 5). It is located in the centre of the grouting fan and mapped as near vertical. The fracturing was caused by the mapped geological structure. Fracture area
II is mapped on the west side of the tunnel in section 11720. This fracture area was also observed in section 11720 in the MWD data. It was interpreted as a continuation of fracture area I in both the MWD and mapping data. Area II extents to fracture area III observed crossing the tunnel west to east between section 11725 and section 11730, at the edge of two grouting fans. In the MWD data, fracture area III was only found in the given sections on the west side of the tunnel (IIIa). On the east side of the tunnel, the fractured areas are displayed 5-m to 10-m further north in the MWD data (IIIb), namely in section 11735 instead of section 11730 (see Table 5). This difference might be caused by the distance between the mapped tunnel roof and the grout-hole location. In practice, the data may be sampled 5-m apart, the distance of the grout holes from the tunnel roof. The mapped fracture area (IIIb) showed a $70^{\circ}$ dip towards the south. Therefore, fracture area IIIb may be located 2-m north in the MWD data. The weak rock mass in the roof is observed by both the contractor and the engineering geologist. The geotechnical description notes a large horizontal structure that creates over-break along the roof between sections 11742 and 11730 . The additional discrepancy may be caused by a changing dip in the fracture area, imprecision during the mapping, or drill-hole deviation. In both the mapping and the MWD data, fracture area IV was observed in section 11745. The MWD data showed this fracture area as a continuation of fracture areas I-III; this continuation was not observed in the documented tunnel mapping but was addressed in the rock mass description made in conjunction with the mapping. Fracture areas V and VI are relatively small but observed in both the mapping and the MWD data at sections 11765 and 11778 .

Given the correlation between the combined normalized penetration rate and rotation pressure, the RQD and the $Q_{\text {base-values, the MWD data may be employed to predict }}$ the rock support needs. Figure 16 and Table 6 display the combined normalized penetration rate and rotation pressure (fracture index), bolt spacing and sprayed concrete thickness in Tunnel 201 between sections 11700 and 11780 . The area in sections 11700 to 11707 shows a fair quality rock mass in the MWD-derived data; this translates into a $1.5-\mathrm{m}$ 


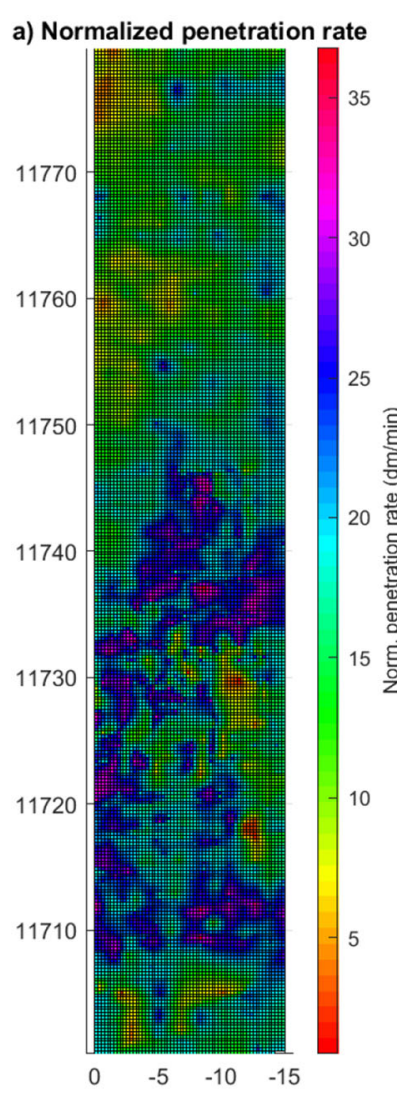

Offset from center line $(\mathrm{m})$

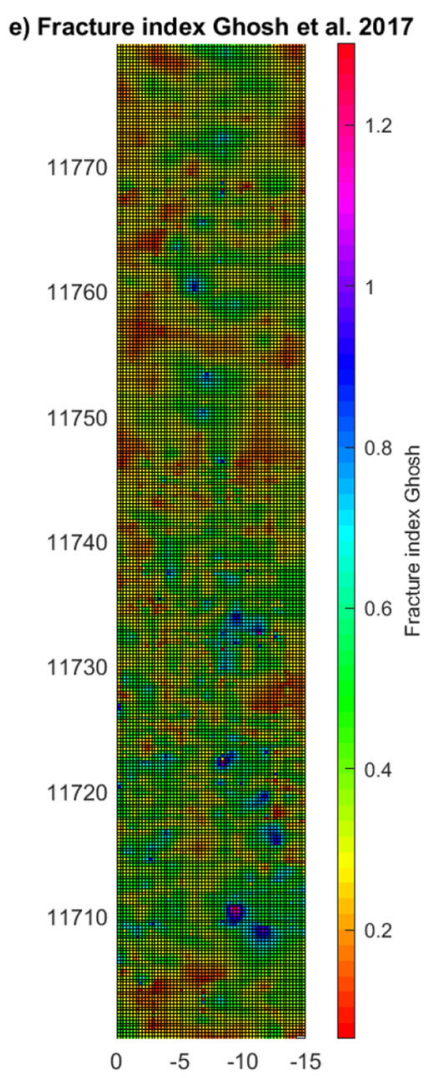

Offset from center line $(\mathrm{m})$ b) Normalized rotation pressure

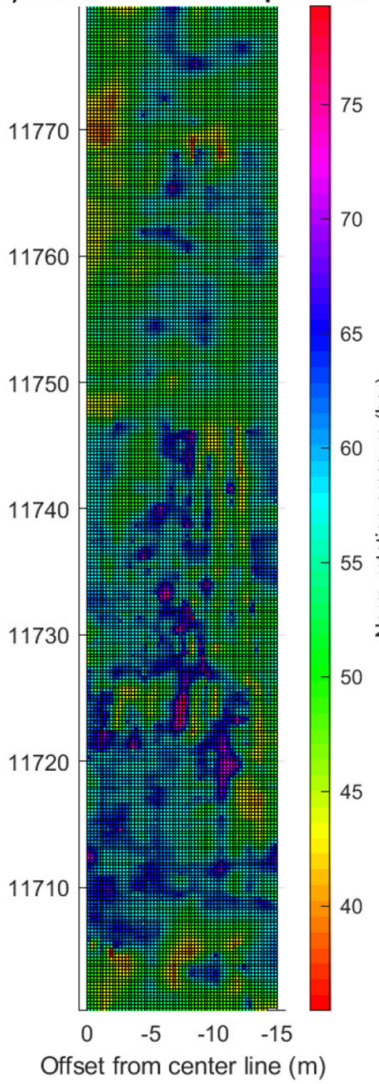

f) Norm.PR+Norm.RP

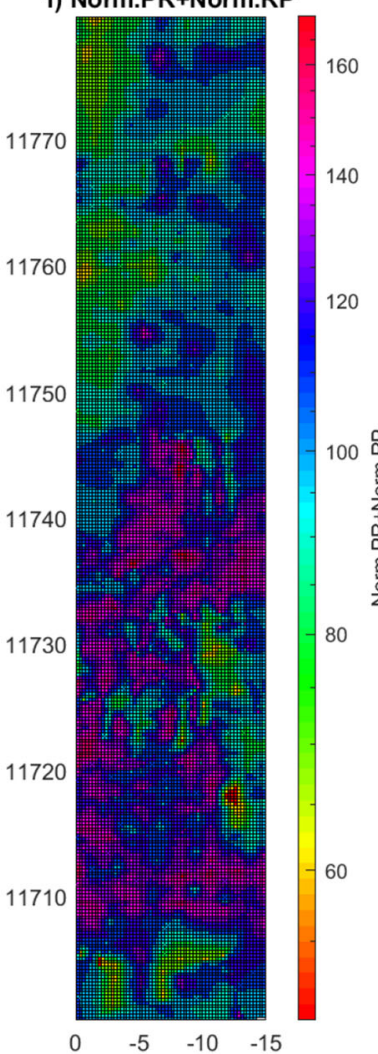

Offset from center line (m) c) Normalized water pressure

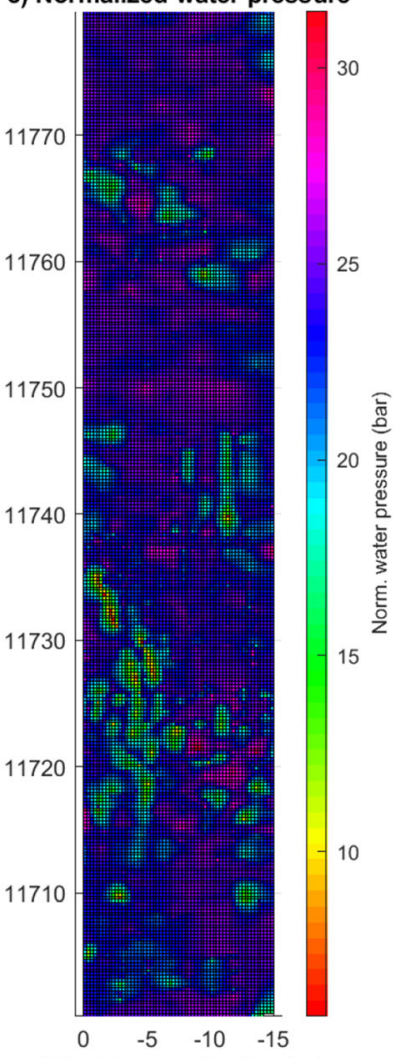

Offset from center line (m)

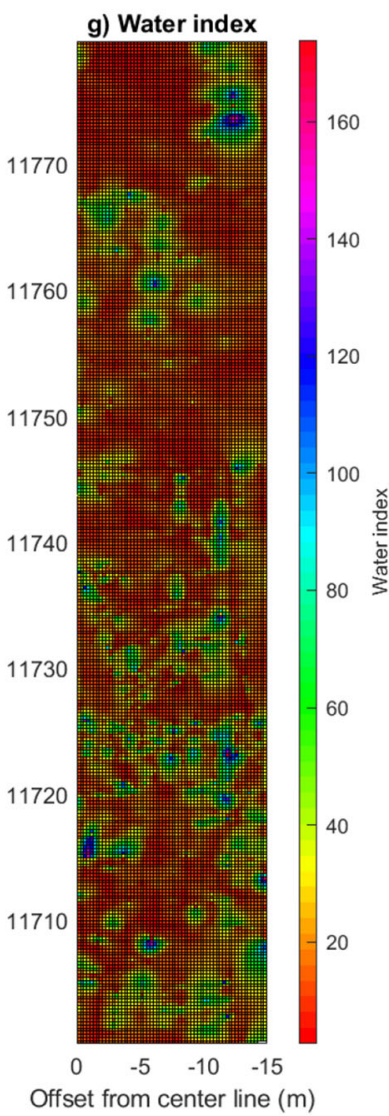

d) Fracture index Epiroc

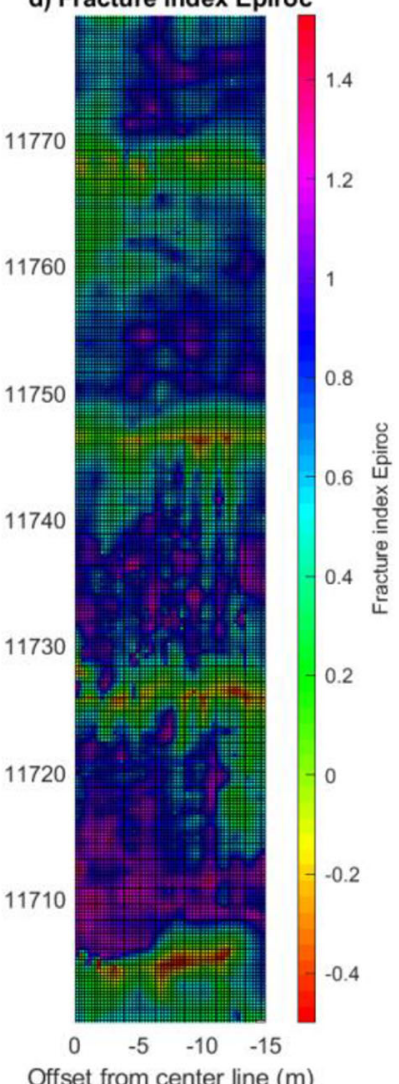

Offset from center line $(\mathrm{m})$

h) base $_{\text {-value }}$

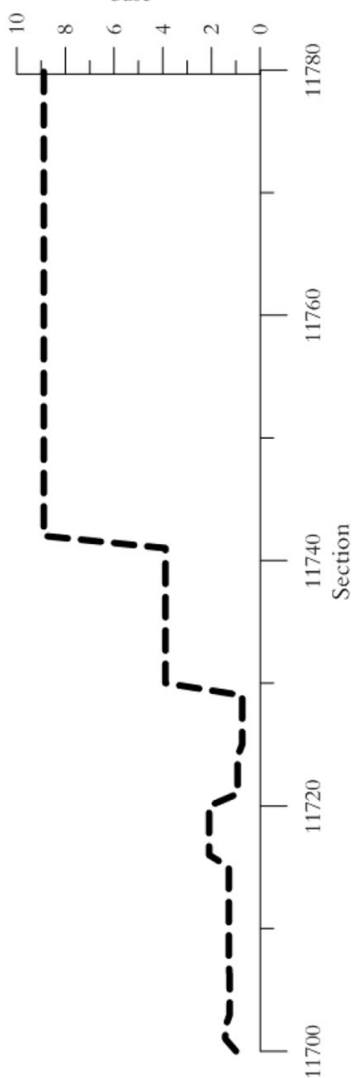

Fig. $13 \mathbf{a}-\mathbf{h}$ Visualizations of the MWD parameters and $Q_{\text {base }}$ in the roof of Tunnel 201 sections 11700-11780 
Fig. 14 Combined normalized penetration rate and rotation pressure, $\mathbf{a} \mathrm{RQD}$ and $\mathbf{b} \mathrm{Qbase}^{-}$ value along Tunnel 201 sections 11700 to 11780 . A lower RQD and $Q_{\text {base-value corresponds with }}$ a higher combined normalized penetration rate and rotation pressure
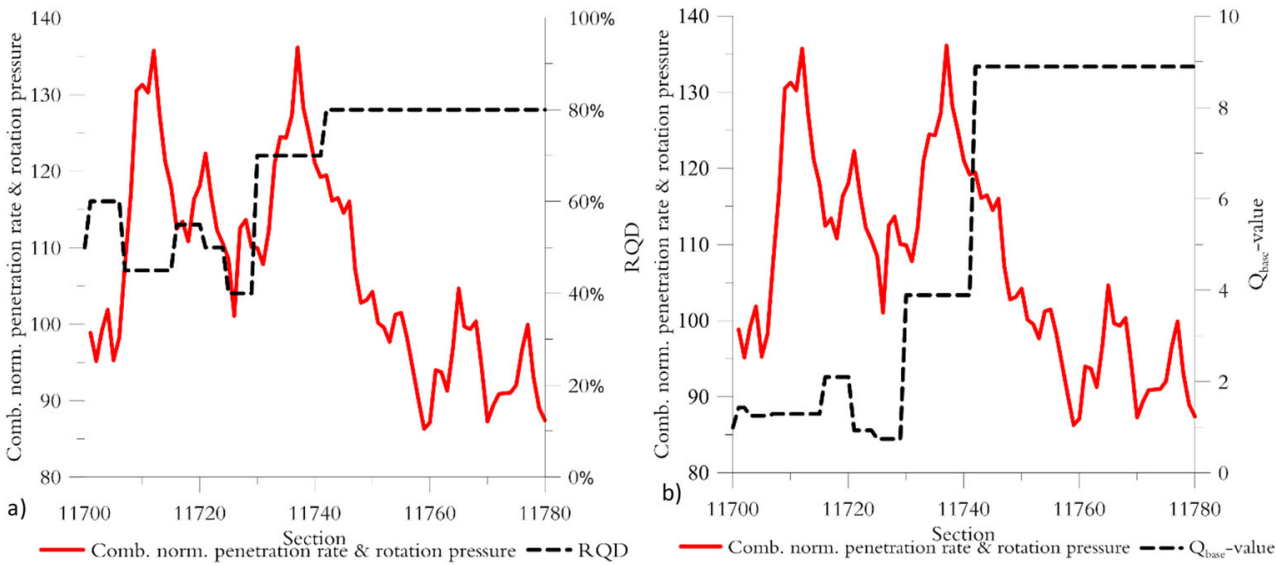

bolt spacing and a 100-mm sprayed concrete layer. At sections 11707 to 11716 , weaker, more fractured rock mass registered by the MWD data results in an increased rock mass support, 1.25-m bolt pattern and 200-mm sprayed concrete thickness. Between sections 11716 and 11721 , the rock mass quality partly improves (especially on the right side of the tunnel), resulting in an increased bolt spacing and reduced sprayed concrete thickness. In the sections between 11721 and 11730 , the MWD data show no significant difference from previous sections, but the rock support was increased by thickening the sprayed concrete liner to $150-\mathrm{mm}$ and reducing the bolt spacing to $1.25-\mathrm{m}$. Further along, in sections 11730 to11742, the MWD parameters do not display a significant rock mass improvement, but the rock support was reduced. In sections 11742 to 11780 , the MWD parameters indicate an improvement in rock mass quality. This improvement resulted in a reduced level of rock support, with 2-m bolt spacing and 75-mm sprayed concrete liner.

Based on the results of the holistic approach, thresholds for the combined normalized penetration rate and rotation pressure (fracture index) can be designated. The study shows, in this case, that with a general combined normalized penetration rate and rotation pressure of 120 or lower, a 2-m bolt spacing and a sprayed concrete layer of 75-mm-100-mm are sufficient. With a combined normalized penetration rate and rotation pressure between 120 and 150, the tunnel roof requires an increased amount of rock support: a $100-\mathrm{mm}$ - to $150-\mathrm{mm}$ thick layer of sprayed concrete and a bolt spacing of 1.25$\mathrm{m}-1.5-\mathrm{m}$. Lastly, if the combined normalized penetration rate and rotation pressure is over 150 , a thick sprayed concrete layer of $200-\mathrm{mm}$ and a tight bolt spacing of $1.25-\mathrm{m}$ are required to support the rock mass.

\section{Concluding remarks}

The comparison of the MWD parameters and rock mass conditions and rock support using multilinear regression and Levenberg-Marquardt methods yielded unsatisfactory results. However, the use of a holistic approach in this case study showed an applicable method for implementing MWD data as a support tool for rock mass classification and rock support design. The

Table 5 Observed fracture areas in tunnel 201, sections 11700 to 11780

Fracture Section mapped Section MWD Description

area

\begin{tabular}{|c|c|c|c|}
\hline I & $11708-11716$ & $11707-11715$ & Large area, across the tunnel, seen at same sections in mapping and MWD data \\
\hline II & $11716-11722-$ & $11715-11722$ & $\begin{array}{l}\text { Large area, west side of the tunnel, seen at same sections in mapping and MWD data, } \\
\text { the continuation of area I }\end{array}$ \\
\hline IIIIa & $11722-11730$ & $11726-11733$ & $\begin{array}{l}\text { Large area, west-east across the tunnel, west side of the tunnel, IIIa seen at same sections in mapping and } \\
\text { MWD data, a continuation of areas I and II }\end{array}$ \\
\hline IIIlb & $11724-11732$ & $11732-11741$ & $\begin{array}{l}\text { Large area, west-east across the tunnel at } 70^{\circ} \text { dip, east side of the tunnel, IIIb as seen } 5-\mathrm{m}-10-\mathrm{m} \text { further } \\
\text { north in the MWD data, on the edge of the grouting fan, } \\
\text { weak rock mass observed by geologist and contractor, the continuation of areas I and II }\end{array}$ \\
\hline IV & $11743-11746$ & $11740-11747$ & $\begin{array}{l}\text { Medium area, at the centre of tunnel roof, seen at same sections in mapping and MWD data, } \\
\text { the continuation of areas I-III }\end{array}$ \\
\hline 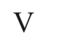 & $11765-11772$ & $11760-11767$ & Small area, at the east side of the tunnel, seen at same sections in mapping and MWD data \\
\hline II & $11774-11779$ & $11777-11778$ & Small area, at the centre and east side of the tunnel, seen at same sections in mapping and MWD data \\
\hline
\end{tabular}




\section{a) Geological mapping}

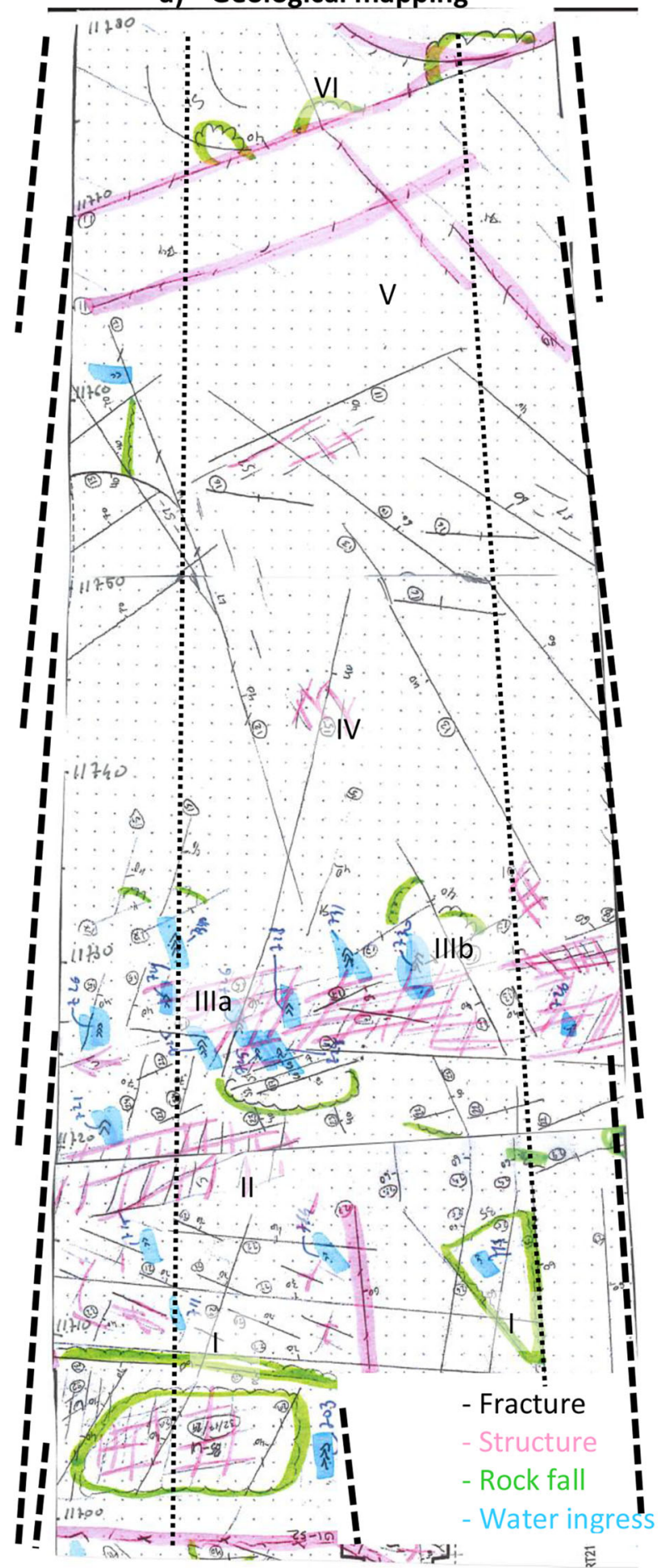

b) Norm.PR+Norm.RP

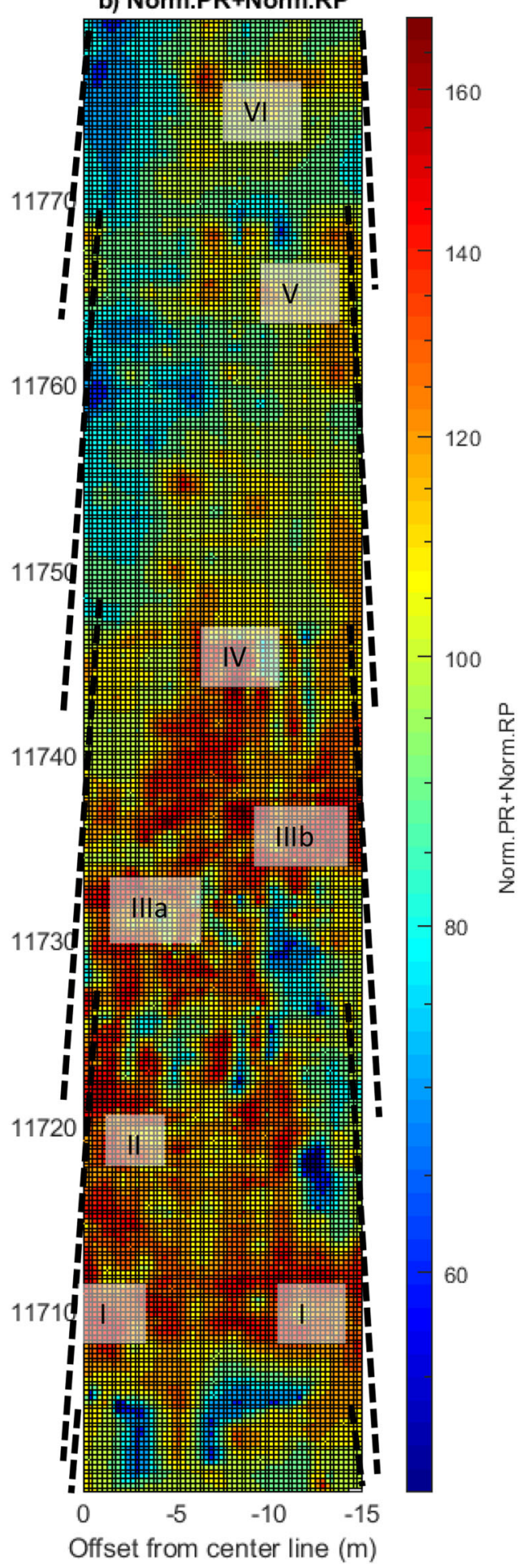

Fig. 15 a Geotechnical mapping and b MWD fracture index in Tunnel 201 between sections 11700 and 11780

MWD data can reliably detect fractured areas observed during the rock mass classification at the time of tunnel excavation. The objectively measured MWD data and fracture index can decisively separate fractured and unfractured rock masses and show a close relationship with rock support requirements.
This holistic method should be incorporated into rock support design as part of the observational method for rock mass support design. This new method should not be seen as a replacement for the current approach using such rock mass classification systems as Bieniawski's RMR system (1973), Barton et al.'s $Q$-system (1974), or Hoek and Brown's GSI 
Table 6 Rock mass condition and rock support in sections 11700 to 11780

\begin{tabular}{|c|c|c|c|c|c|}
\hline Section & Rock mass condition based on MWD & MWD factor index & $\begin{array}{l}\text { Mapped } \\
Q_{\text {base }}\end{array}$ & $\begin{array}{l}\text { Bolt spacing } \\
(\mathrm{m})\end{array}$ & $\begin{array}{l}\text { Sprayed concrete } \\
\text { thickness }(\mathrm{mm})\end{array}$ \\
\hline $11700-11707$ & Fair rock mass quality & $55-120$ & 1.3 & 1.5 & 100 \\
\hline $11707-11716$ & $\begin{array}{l}\text { Weaker, more fractured rock mass, } \\
\text { but increased } Q_{\text {base }}\end{array}$ & $100-150$ & 1.8 & 1.25 & 200 \\
\hline $11716-11721$ & Improved quality, especially east side & $\begin{array}{l}50-100 \text { (east) } 100-160 \\
\quad \text { (west) }\end{array}$ & 2.4 & $\begin{array}{l}1.4 \text { (west), } 1.5 \\
\quad \text { (east) }\end{array}$ & 100 (east), 150 (west) \\
\hline $11721-11730$ & $\begin{array}{l}\text { Improved rock mass quality in the centre of the } \\
\text { roof }\end{array}$ & $\begin{array}{l}60-100 \text { (east) } 80-140 \\
\quad \text { (west) }\end{array}$ & 0.8 & 1.25 & 150 \\
\hline $11730-11742$ & Fractures across tunnel roof & $100-170$ & 3.9 & 2.0 & 100 \\
\hline $11742-11780$ & $\begin{array}{l}\text { Small fracture areas, fairly homogeneous MWD } \\
\text { fracture index }\end{array}$ & $60-120$ & 8.9 & 2.0 & 75 \\
\hline
\end{tabular}

(1997). Rather, it should be considered an additional data source for rock mass classification and rock support design. As the method is established based on a limited number rock support designs in an 80-m tunnel stretch, it should be developed further and tested in other excavations.
From this study, the following can be concluded:

- The penetration rate and rotation pressure residuals at Tunnel 201 in the Stockholm bypass have a semi-normal distribution;
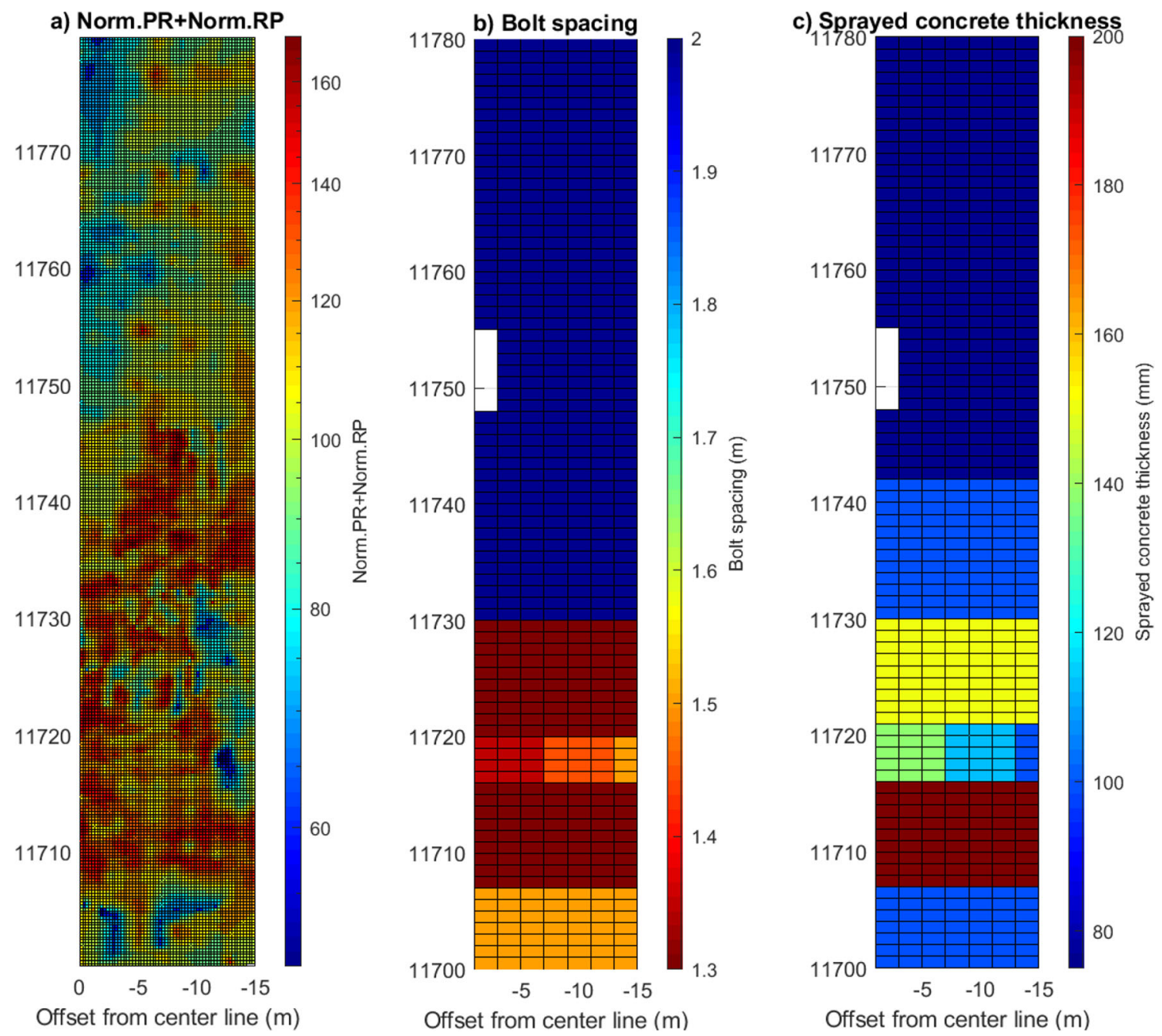

Offset from center line (m)

Fig. 16 a-c Fracture index and the bolt spacing and sprayed concrete thickness in Tunnel 201 between sections 11700 and 11780 
- The data collected for the $Q$-system and the rock support to be installed show an incremental normal distribution because the data were recorded in increments;

- The multilinear regression showed a moderate to a strong correlation between the mean MWD values and the $Q$ parameters;

- The multilinear regression showed no correlation between the residual MWD values and the $Q$-parameters;

- The Levenberg-Marquardt method demonstrated the predictive capability of MWD residuals for the $Q$-system parameters and the rock support in tunnelling, albeit with low precision;

- The holistic visual approach showed good results; the normalized MWD parameters and their indices have a good resemblance with the RQD and the $Q_{\text {base-value; }}$

- The holistic visual approach using the MWD combined normalized penetration rate and rotation pressure (fracture index) can reliably distinguish more of the fractured areas observed in the geotechnical mapping;

- The holistic visual approach showed MWD data can be applied to predict rock support requirements in tunnelling because of the correlation of the fracture index with the installed rock support;

- The holistic approach using MWD data should be a tool incorporated in the observational method for rock support assessment.

Acknowledgments Open access funding provided by Lulea University of Technology. The authors thank Subterra Sweden AB, Å, and the Swedish Transport Administration (Trafikverket) for their contribution of MWD data and rock support advice.

Funding information This work was financially supported by BeFo (Rock Engineering Research Foundation) and Swebrec (Swedish Blasting Research Centre).

\section{Compliance with ethical standards}

Conflict of interest The authors declare that they have no conflict of interest.

\section{Appendix}

Table 7 Initial rock classification at Tunnel 201

\begin{tabular}{|c|c|c|c|c|c|c|c|c|c|c|c|c|c|c|c|}
\hline Tunnel & 201 & Description & Rock type & RQD & $J_{\mathrm{n}}$ & $J_{\mathrm{n}, \text { corrected }}$ & $J_{\mathrm{r}}$ & $J_{\mathrm{a}}$ & $J_{\mathrm{w}}$ & SRF & $Q_{\text {base }}$ & $Q$ & Remarks & $\begin{array}{l}\text { Rock } \\
\text { cover } \\
(\mathrm{m})\end{array}$ & $\begin{array}{l}\text { Rock } \\
\text { class }\end{array}$ \\
\hline 11629 & 11710 & & Gneiss & 90 & 6 & 6 & 3 & 2 & 1 & 1 & 22.5 & 22.5 & & $45-50$ & I \\
\hline 11710 & 11725 & $\begin{array}{l}\text { Ramp } \\
\quad \text { connection }\end{array}$ & & 90 & 6 & 6 & 3 & 2 & 1 & 1 & 22.5 & 22.5 & & $45-50$ & I \\
\hline 11725 & 11755 & $\begin{array}{l}\text { SZ\#169, Ramp } \\
\text { connection }\end{array}$ & Gneiss & 40 & 6 & 6 & 2 & 2 & 0.66 & 5 & 6.7 & 0.9 & $\begin{array}{l}J_{\mathrm{w}}=0,66 \text { risk of water-filled fractures. } \\
\mathrm{SRF}=5 \text { weak zone at } \leq 50 \text {-m tunnel } \\
\text { depth }\end{array}$ & $48-59$ & IV \\
\hline 11755 & 11845 & & Gneiss & 90 & 6 & 6 & 3 & 2 & 1 & 1 & 22.5 & 22.5 & & $>50$ & I \\
\hline 11845 & 11856 & SZ\#164 & $\begin{array}{l}\text { Gneiss, } \\
\text { Granit- } \\
\text { e }\end{array}$ & 40 & 6 & 6 & 2 & 2 & 0.66 & 2.5 & 6.7 & 1.8 & $\begin{array}{l}\text { Values for expected weak zone. } J_{\mathrm{w}}=0.66 \\
\text { risk of water-filled fractures. } \\
\mathrm{SRF}=2.5 \text {, weak zone at }>50 \text {-m tunnel } \\
\text { depth }\end{array}$ & $>50$ & III \\
\hline 11856 & 11890 & $\begin{array}{l}\text { T-intersection, } \\
\text { SZ\#164 }\end{array}$ & $\begin{array}{l}\text { Gneiss, } \\
\text { Granit- } \\
\text { e }\end{array}$ & 40 & 6 & 12 & 2 & 2 & 0.66 & 2.5 & 6.7 & 0.9 & $\begin{array}{l}\text { Values for expected weak zone. } J_{\mathrm{w}}=0.66 \\
\text { risk of water-filled fractures. } \\
\mathrm{SRF}=2.5 \text {, weak zone at }>50 \text {-m tunnel } \\
\text { depth }\end{array}$ & $>50$ & IV \\
\hline 11890 & 11903 & T-intersection & $\begin{array}{l}\text { Gneiss, } \\
\text { Granit- } \\
\mathrm{e}\end{array}$ & 90 & 6 & 12 & 3 & 2 & 1 & 1 & 22.5 & 11.3 & & $>50$ & I \\
\hline 11903 & 11920 & & $\begin{array}{l}\text { Gneiss. } \\
\text { Granit- } \\
\text { e }\end{array}$ & 90 & 6 & 6 & 3 & 2 & 1 & 1 & 22.5 & 22.5 & & $>50$ & I \\
\hline 11920 & 11945 & SZ\#239 & $\begin{array}{l}\text { Gneiss, } \\
\text { Granit- } \\
\text { e }\end{array}$ & 40 & 6 & 6 & 2 & 2 & 0.66 & 2.5 & 6.7 & 1.8 & $\begin{array}{l}\text { Values for expected weak zone. } J_{\mathrm{w}}=0.66 \\
\text { risk of water-filled fractures. } \\
\mathrm{SRF}=2.5 \text {, weak zone at }>50 \text {-m tunnel } \\
\text { depth }\end{array}$ & $>50$ & III \\
\hline 11945 & 12115 & & & 90 & 6 & 6 & 3 & 2 & 1 & 1 & 22.5 & 22.5 & & $>50$ & I \\
\hline
\end{tabular}


Table 7 (continued)

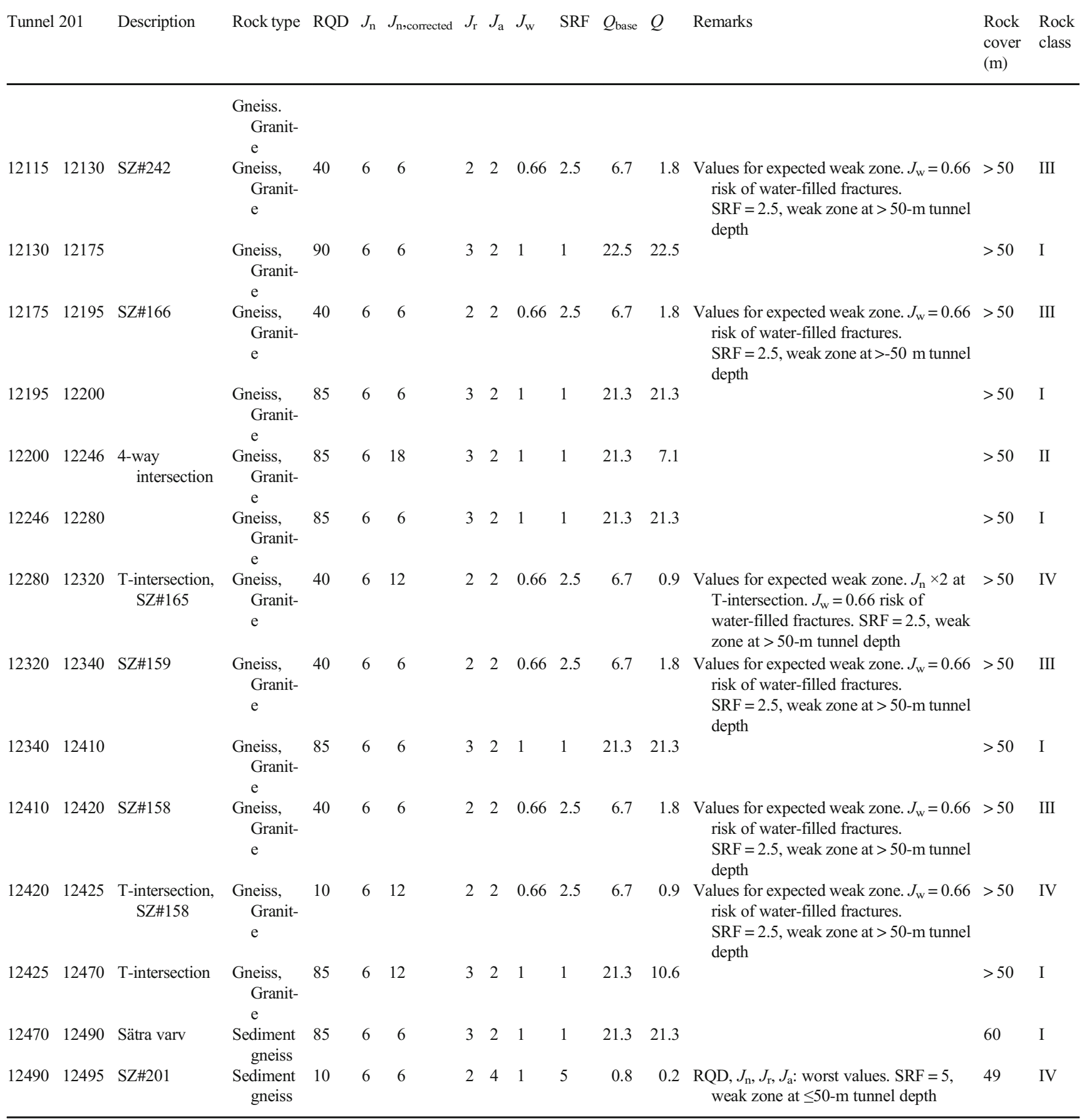


Open Access This article is licensed under a Creative Commons Attribution 4.0 International License, which permits use, sharing, adaptation, distribution and reproduction in any medium or format, as long as you give appropriate credit to the original author(s) and the source, provide a link to the Creative Commons licence, and indicate if changes were made. The images or other third party material in this article are included in the article's Creative Commons licence, unless indicated otherwise in a credit line to the material. If material is not included in the article's Creative Commons licence and your intended use is not permitted by statutory regulation or exceeds the permitted use, you will need to obtain permission directly from the copyright holder. To view a copy of this licence, visit http://creativecommons.org/licenses/by/4.0/.

\section{References}

ÅF (2016-2018) Project E4 Förbifart Stockholm, Kartering och förstärkningsanvisning. Internal working documents

Arghe F (2016) E4 Förbifart Stockholm FSE209 Bergtunnlar Skärholmen - Ingenjörsgeologisk prognos - Bergteknik Handling 13.5 - Bygghandling 2015-03-04 (Rev B 2016-03-17) 2B141102FSE209. Technical report (in Swedish)

Atlas Copco (2009) Atlas Copco face drilling options measurement while drilling technical specification. 98512456 01a 02/2009

Barton N, Lien R, Lunde J (1974) Engineering classification of rock masses for design of tunnel support. Rock Mech 6(4):189-236

Bieniawski ZT (1973) Engineering classification of jointed rock masses. Civil Eng S Afr 15(12):335-344

Cesano F, Olofsson B, Bagtzoglou AC (2000) Parameters regulating groundwater inflows into hard rock tunnels - a statistical study of the Bolmen tunnel in southern Sweden. Tunn Undergr Sp Tech 15(2): $153-165$

Deere DU (1964) Technical description of rock cores for engineering purposes. Rock Mech Eng Geol 1(1):16-22

Ghosh R, Danielsson M, Gustafson A, Falksund H, Schunnesson H (2017) Assessment of rock mass quality using drill monitoring technique of hydraulic ITH drills. Int J Min Miner Process Eng 8(3): $169-186$

Heath MT (2002) Scientific computing - an introductory survey, 2nd edn. McGraw-Hill, New York
Hoek E, Brown ET (1997) Practical estimates of rock mass strength. Int J Rock Mech Min Sci 34(8):1165-1186

Martinsson L, Bengtsson F (2010) Tillämpning av MWD vid utformning av injektering. BKs 55:e årsmöte 2010, March 9, 2010, Bergsprängningskommittén, Stockholm, Sweden (in Swedish)

Navarro J, Sanchidrián JA, Segarra P, Castedo R, Costamagna E, López LM (2018) Detection of potential overbreak zones in tunnel blasting from MWD data. Tunn Undergr Space Technol 82:504-516

NGI (2015) Using the Q-system - rock mass classification and support design - rock mass classification and support design. Handbook

Peck RB (1969) Advantages and limitations of the observational method in applied soil mechanics. Geotechnique 19(2):171-187

Rødseth M (2013) Analyse av sammenhenger mellom MWD-data og bergmekaniske parameter. Master thesis, Norges teknisknaturvitenskapelige universitet, Trondheim, Norway

Schunnesson H (1996) RQD predictions based on drill performance parameters. Tunn Undergr Space Technol 11(3):345-351

Schunnesson H (1998) Rock characterisation using percussive drilling. Int J Rock Mech Min Sci 35(6):711-725

Schunnesson H, Elsrud R, Rai P (2011) Drill monitoring for ground characterization in tunnelling operations. Proc. 20th International Symposium on Mine Planning and Equipment Selection (MPES2011), National Center on Complex Procession of Mineral Raw Materials of the Republic of Kazakhstan, Almaty, Kazakhstan

Trafikverket (2018) https://www.trafikverket.se/contentassets/ 5fd4779c3bfa4adbac7ba1c296598f12/upphandling_fs_webb.pdf. Accessed 11 March 2019

Van Eldert J, Schunnesson H, Johansson D, Saiang D (2018) Measurement while drilling (MWD) technology for blasting damage calculation. Fragblast12, 9-15 June 2018, Luleå tekniska universitet, Luleå, Sweden

Van Eldert J, Schunnesson H, Johansson D, Saiang D (2020a) Application of measurement while drilling technology to predict rock mass quality and rock support for tunnelling. Rock Mech Rock Eng 53:1349-1358. https://doi.org/10.1007/s00603-01901979-2

Van Eldert J, Schunnesson H, Saiang D, Funehag J (2020b) Improved filtering and normalizing of measurement while drilling data in tunnel excavation tunnelling and underground space technology V103. https://doi.org/10.1016/j.tust.2020.103467 